\title{
Energy Conversion and Storage: The Value of Reversible Power-to-Gas Systems
}

\author{
Gunther Glenk \\ Mannheim Institute for Sustainable Energy Studies, University of Mannheim \\ MIT CEEPR, Massachusetts Institute of Technology \\ glenk@uni-mannheim.de \\ Stefan Reichelstein \\ Mannheim Institute for Sustainable Energy Studies, University of Mannheim \\ Graduate School of Business, Stanford University \\ Leibniz Centre for European Economic Research (ZEW) \\ reichelstein@uni-mannheim.de
}




\begin{abstract}
In the transition to decarbonized energy systems, Power-to-Gas (PtG) processes have the potential to connect the existing markets for electricity and hydrogen. Specifically, reversible PtG systems can convert electricity to hydrogen at times of ample power supply, yet they can also operate in the reverse direction to deliver electricity during times when power is relatively scarce. Here we develop a model for determining when reversible PtG systems are economically viable. We apply the model to the current market environment in both Germany and Texas and find that the reversibility feature of unitized regenerative fuel cells (solid oxide) makes them already cost-competitive at current hydrogen prices, provided the fluctuations in electricity prices are as pronounced as currently observed in Texas. We further project that, due to their inherent flexibility, reversible PtG systems would remain economically viable at substantially lower hydrogen prices in the future, provided recent technological trends continue over the coming decade.
\end{abstract}

Keywords: Renewable Energy, Power Markets, Hydrogen, Power-to-Gas, Energy Storage JEL: M2, O3, Q4, Q5 


\section{Introduction}

The large-scale deployment of intermittent renewable energy sources, like wind and solar, has resulted in a growing challenge to balance energy demand and supply in real time ${ }^{112}$. Aside from storage in batteries ${ }^{\sqrt[3]{4}}$, electrolytic hydrogen production via Power-to-Gas (PtG) processes can rapidly absorb electricity during times of ample power supply and thereby yield valuable hydrogen for industrial customers ${ }^{5+7}$. Conversely, PtG systems that are also capable of operating in the reverse direction can convert hydrogen back to electricity during periods of limited power supply and correspondingly high power prices $\frac{899}{}$. Thus, reversible PtG systems can effectively connect the markets for hydrogen and electricity ${ }^{10}$ [12, and in the process limit the growing price volatility in electricity markets $13 \mid 14$.

Reversible PtG systems can be designed in a modular manner, for instance by combining a one-directional electrolyzer for hydrogen production with a one-directional fuel cell or gas turbine for power generation 15116 . While electrolyzers have been found to become increasingly cost-competitive in producing hydrogen ${ }^{17 / 18}$, fuel cells and gas turbines have so far been regarded as too expensive for converting hydrogen back to electricity that is then sold in wholesale markets ${ }^{919 / 20}$. In contrast, unitized regenerative fuel cells, which we refer to as integrated PtG systems, utilize the same equipment to deliver either hydrogen or electricity depending on the prevailing electricity prices at different points in time 2123 .

This paper first develops an analytical model of the unit economics of reversible PtG systems. Our necessary and sufficient conditions show that the technological characteristics of both modular and integrated systems entail specific ranges for hydrogen prices at which reversible PtG systems become cost-competitive. While modular systems require sufficiently low hydrogen prices in order for the reversibility feature to be valuable, integrated systems can be economically viable for higher hydrogen prices by primarily generating hydrogen but also providing electricity during times of limited power supply. Such operations will therefore not only increase the supply of hydrogen but provide an effective buffer against the intermittency of renewable power sources.

The empirical part of our analysis calibrates the model in the context of the electricity markets in Germany and Texas. Despite improvements in the cost and conversion efficiency of modular PtG systems ${ }^{2425}$, we confirm the findings of earlier studies that there is no economic case, either now or in the foreseeable future, for investing in modular systems that convert hydrogen back to electricity. In contrast, integrated PtG systems based on solid 
oxide cell (SOC) technology are shown to be competitive at current hydrogen prices, given sufficient variation in daily electricity prices, as is already encountered in the Texas market. For such systems, it is indeed efficient to mostly produce hydrogen and respond to sufficiently high electricity prices with electric power production. Owing to their relatively high capacity utilization, integrated systems are also positioned more competitively than one-directional electrolyzers on their own.

Finally, we project that if recent trends regarding the acquisition cost and conversion efficiency of solid oxide fuel cells continue, such reversible PtG systems will remain economically viable even in the presence of substantially lower hydrogen prices in the future. This is because the inherent flexibility in these systems enables them to respond to lower hydrogen prices by operating more frequently in reverse mode, delivering additional electricity to the power markets.

\section{Real-time Operation of Reversible Power-to-Gas}

We examine reversible PtG systems that can (i) produce hydrogen via water electrolysis and (ii) produce electricity from hydrogen and oxygen 26 . We refer to such systems as modular if the two production processes run on separate devices, such as a one-directional electrolyzer for hydrogen production and a one-directional fuel cell or gas turbine for the reverse operation. In contrast, we refer to a unitized regenerative fuel cell based on, for instance, a solid oxide cell $(\mathrm{SOC})^{10 \mid 27}$ or a proton exchange membrane $(\mathrm{PEM})^{[22128}$ technology as an integrated reversible PtG system. Such systems can carry out both production processes on the same equipment, yet they can only run in at most one direction at any point in time.

Since our interest is in the economics of reversible PtG systems, we focus on such systems operating on their own as price takers in a wholesale market for electricity in which prices are determined hourly based on supply and demand. Time is modeled as a continuous variable $t$ ranging from 0 to 8,760 hours per year. Let $q(t)$ denote the market price for electricity per kilowatt-hour $(\mathrm{kWh})$ at time $t$. We initially assume that the annual distribution of power prices remains constant across the lifetime of the system. Symbols and acronyms are listed in Supplementary Table 1.

For the purposes of our economic analysis, there is no loss of generality in normalizing capacity investments for either the modular or the integrated system to 1 kilowatt $(\mathrm{kW})$ of electricity input or output. We initially assume that either reversible PtG system can be 
brought instantaneously to full operating temperature. Earlier studies have shown that the cost of maintaining the temperature of well-insulated systems is likely minor 29 . Furthermore, the conversion efficiencies considered throughout our analysis account for efficiency losses incurred for maintaining the operating temperature. Once the electrolyzer and fuel cell technologies we consider have reached their full operating temperature up- and down-ramping can be conducted in seconds $\frac{10 \mid 22[30}{}$. The corresponding capacity factors, which are denoted by $C F$ and reflect the percentage of the available capacity utilized at time $t$, can then be chosen flexibly on the interval $[0,1]$. In an extension to the basic model, Supplementary Note 1 shows that the losses incurred by bringing the system from a cold start to full operating temperature only entail a relatively minor cost for the technology and market settings we consider.

If the modular system generates hydrogen at time $t$, it earns a "conversion price" consisting of the market price of hydrogen, $p$, per kilogram $(\mathrm{kg})$ multiplied with the conversion rate of going from electricity to hydrogen (in $\mathrm{kg} / \mathrm{kWh}$ ). The hydrogen price, $p$, is modeled as time-invariant, because buyers and suppliers typically sign fixed-price contracts 31 . The corresponding conversion parameter $\eta_{h}^{o}\left(C F_{h}^{o}\right)$ represents the amount of hydrogen (in $\mathrm{kg}$ ) that can be generated from $1 \mathrm{kWh}$ of electricity, given a capacity utilization of $C F_{h}^{o}$. The variable cost of hydrogen generation equals $q(t)$ plus a cost increment $w_{h}^{o}$ per $\mathrm{kWh}$ that accounts for consumable inputs, like water and reactants for deionizing the water, as well as any purchasing mark-ups on the wholesale price of electricity.

Given a hydrogen price, $p$, the contribution margin from hydrogen production with the modular reversible PtG system at time $t$ (in $\$ / \mathrm{kWh}$ ) thus is:

$$
C M_{h}^{o}\left(C F_{h}^{o}, t \mid p\right)=\left[\eta_{h}^{o}\left(C F_{h}^{o}\right) \cdot p-q(t)-w_{h}^{o}\right] \cdot C F_{h}^{o}
$$

Conversely, if the modular system generates electricity, it earns $q(t)$ and incurs a variable cost that comprises $p$ and an incremental cost, $w_{e}^{o}$, per $\mathrm{kWh}$ of electricity for transporting hydrogen to the Gas-to-Power (GtP) system. To account for efficiency losses, the cost of hydrogen, $p$, is marked-up by the conversion rate for power generation, $\eta_{e}^{o}\left(C F_{e}^{o}\right)(\mathrm{in} \mathrm{kWh} / \mathrm{kg})$. The shape of the functions $\eta_{h}^{o}(\cdot)$ and $\eta_{e}^{o}(\cdot)$ depends on the particular technology considered. The contribution margin of electricity generation per $\mathrm{kWh}$ at time $t$ then becomes:

$$
C M_{e}^{o}\left(C F_{e}^{o}, t \mid p\right)=\left[q(t)-\frac{p}{\eta_{e}^{o}\left(C F_{e}^{o}\right)}-w_{e}^{o}\right] \cdot C F_{e}^{o}
$$


Efficient utilization of the existing capacity is obtained if the capacity factors are at each point in time chosen to maximize the total available contribution margin. While the modular system can run at full capacity in both directions, the $1^{\text {st }}$ Law of Thermodynamics stipulates that the overall round-trip efficiency must satisfy the inequality $\eta_{h}^{o}(\cdot) \cdot \eta_{e}^{o}(\cdot) \leq 1$ for all $0 \leq C F_{h}^{o}, C F_{e}^{o} \leq 1$. Consequently, at most one of the terms $\left[\eta_{h}^{o}\left(C F_{h}^{o}\right) \cdot p-q(t)-w_{h}^{o}\right]$ or $\left[q(t)-\frac{p}{\eta_{e}^{o}\left(C F_{e}^{o}\right)}-w_{e}^{o}\right]$ will be positive for any given values $w_{h}^{o}, w_{e}^{o} \geq 0$. As illustrated in Figure 1 (see Methods for formal derivations), efficient system utilization thus implies that the capacity factors be chosen so that $C F_{h}^{o} \cdot C F_{e}^{o}=0$. Specifically, the optimal capacity factors, $C F_{h}^{o *}(t \mid p)$ and $C F_{e}^{o *}(t \mid p)$ maximize pointwise the sum of the contribution margins in (1) and (2) (see Methods for details). When aggregated across the hours of a year, the maximized contribution margins will be denoted by $C M_{h}^{o}(p)$ and $C M_{e}^{o}(p)$.

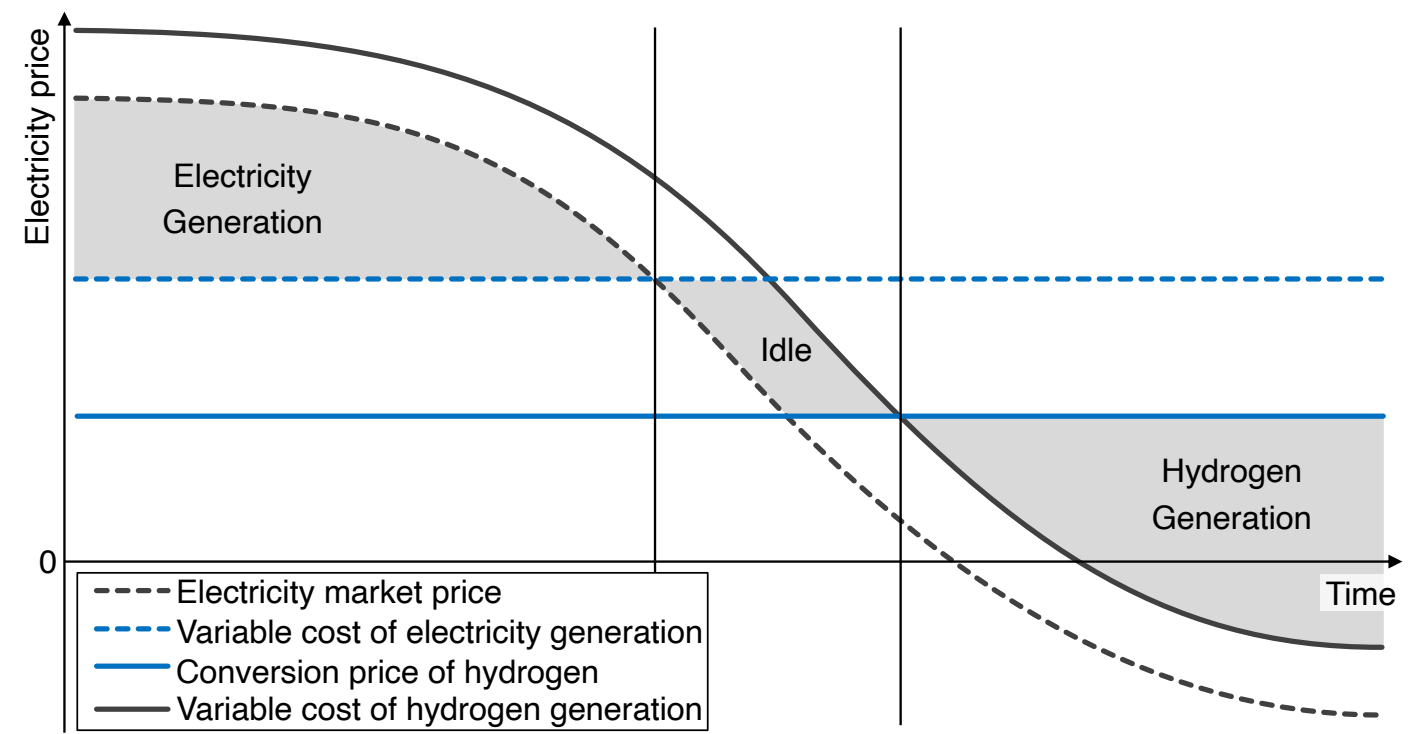

Figure 1. Contribution margins of a reversible Power-to-Gas system. The figure illustrates the three alternative operating modes for either a modular or an integrated reversible PtG system that emerge for varying electricity prices. Wholesale electricity prices can turn negative as a result of surplus energy being supplied to the grid at certain hours.

For the integrated system, the economic trade-off is principally the same, except that the incremental cost and conversion rates may differ and instead assume the values $w_{h}, w_{e}, \eta_{h}(\cdot)$, and $\eta_{e}(\cdot)$, respectively. Once they are at operating temperature, unitized regenerative fuel cells based on SOC or PEM technology can rapidly switch between hydrogen and electricity production at full capacity 22127 . Figure 1 illustrated that, provided there are no sudden jumps in electricity prices, time intervals where electricity generation is valuable will typically be followed by a time interval in which the system is idle before entering a stretch of time where 
the regenerative fuel cell again becomes active in either mode of operation.

By construction, the integrated system faces the technical rather than economic "complementary slackness" condition $C F_{h} \cdot C F_{e}=0$ for all $t$. The corresponding contribution margins are:

$$
C M_{h}\left(C F_{h}, t \mid p\right)=\left[\eta_{h}\left(C F_{h}\right) \cdot p-q(t)-w_{h}\right] \cdot C F_{h}
$$

for hydrogen production, and

$$
C M_{e}\left(C F_{e}, t \mid p\right)=\left[q(t)-\frac{p}{\eta_{e}\left(C F_{e}\right)}-w_{e}\right] \cdot C F_{e}
$$

for electricity. The capacity factors that maximize the sum of the contribution margins in (3) and (4), subject to the complementary slackness constraint, are denoted by $C F_{h}^{*}(t \mid p)$ and $C F_{e}^{*}(t \mid p)$, respectively. Given these capacity factors, we denote by $C M(p)$ the optimized aggregate contribution margin which is obtained as the total contribution margin obtained after integrating (3) and (4) across the hours of the year.

\section{Cost Competitiveness and the Value of Reversibility}

A reversible Power-to-Gas system is said to be cost-competitive if the required upfront investment in equipment yields a positive net-present value in terms of discounted future cash flows. The discounted annual stream of optimized contribution margin of the system must then at least cover the initial equipment expenditure. For direct comparison, it will be convenient to capture this economic trade-off on a levelized basis. Analogous to the commonly known levelized cost of electricity, the Levelized Fixed Cost (LFC) of a reversible PtG system reflects the unit acquisition cost of the system per $\mathrm{kWh}$, including applicable fixed operating costs, corporate income taxes, and the cost of debt and equity 232133 .

For the modular system, the levelized fixed cost per $\mathrm{kWh}$ for the electrolyzer is denoted by $L F C_{h}^{o}$. As shown in Methods, the Power-to-Gas subsystem is cost-competitive (positive net-present value) if and only if at the prevailing market price for hydrogen, $p$ :

$$
C M_{h}^{o}(p)-L F C_{h}^{o}>0
$$

Since the contribution margin from hydrogen is increasing in the selling price of hydrogen, there exists a unique break-even price, $p_{h}^{o}$, such that Power-to-Gas will be cost-competitive 
whenever $p \geq p_{h}^{o}$. Similarly, the Gas-to-Power subsystem is cost-competitive whenever:

$$
C M_{e}^{o}(p)-L F C_{e}^{o}>0
$$

with $L F C_{e}^{o}$ denoting the corresponding levelized fixed cost per $\mathrm{kWh}$. Since the contribution margin from producing electricity is decreasing in the input price for hydrogen, $p$, there also exists a unique break-even price, $p_{e}^{o}$, below which GtP will be cost-competitive.

By design, investors in a modular system retain the option of acquiring only one of the two subsystems. We therefore call the modular system cost-competitive if at least one of its subsystems is cost-competitive. In addition, the reversibility feature of the system is said to be valuable if both subsystems have positive net-present value on their own. The following finding links cost-competitiveness and the value of reversibility to the prevailing market price of hydrogen.

Finding 1: The modular reversible PtG system is cost-competitive if and only if at the prevailing hydrogen market price, $p$, either $p>p_{h}^{o}$ or $p<p_{e}^{o}$. Reversibility of the modular system is valuable if and only if $p \in\left[p_{h}^{o}, p_{e}^{o}\right]$.

Figure 29 illustrates the setting of a modular reversible PtG system that is cost-competitive and for which reversibility is valuable. Note that reversibility of the modular system cannot be of value unless $p_{h}^{o}<p_{e}^{o}$.

For the integrated reversible PtG system, the levelized fixed cost per $\mathrm{kWh}$ of the system is denoted by $L F C$. Cost competitiveness of the integrated system then requires that the optimized aggregate contribution margin, $C M(p)$, exceeds $L F C$. The reversibility of the integrated system is said to be valuable if at the prevailing market price of hydrogen, $p$, investment in the system is cost-competitive and, furthermore, the system operates in both directions for select hours of the year, i.e., both sets $\left\{t \mid C F_{h}^{*}(t \mid p)>0\right\}$ and $\left\{t \mid C F_{e}^{*}(t \mid p)>0\right\}$ have positive length across the hours of the year.

Figure $2 \mathrm{~b}$ illustrates a setting in which the reversibility feature of the integrated reversible PtG system is valuable. We note that when viewed as a function of $p$, the optimized contribution margin, $C M(\cdot)$, is drawn as a U-shaped curve. This follows directly from the convexity of this function in $p$ (see Methods), combined with the observation that $C M(p)$ is increasing for large values of $p$ and again increasing as $p$ becomes small, possibly negative. The U-shape of $C M(\cdot)$ implies that there exist at most two break-even points at which $C M(p)=L F C$. 

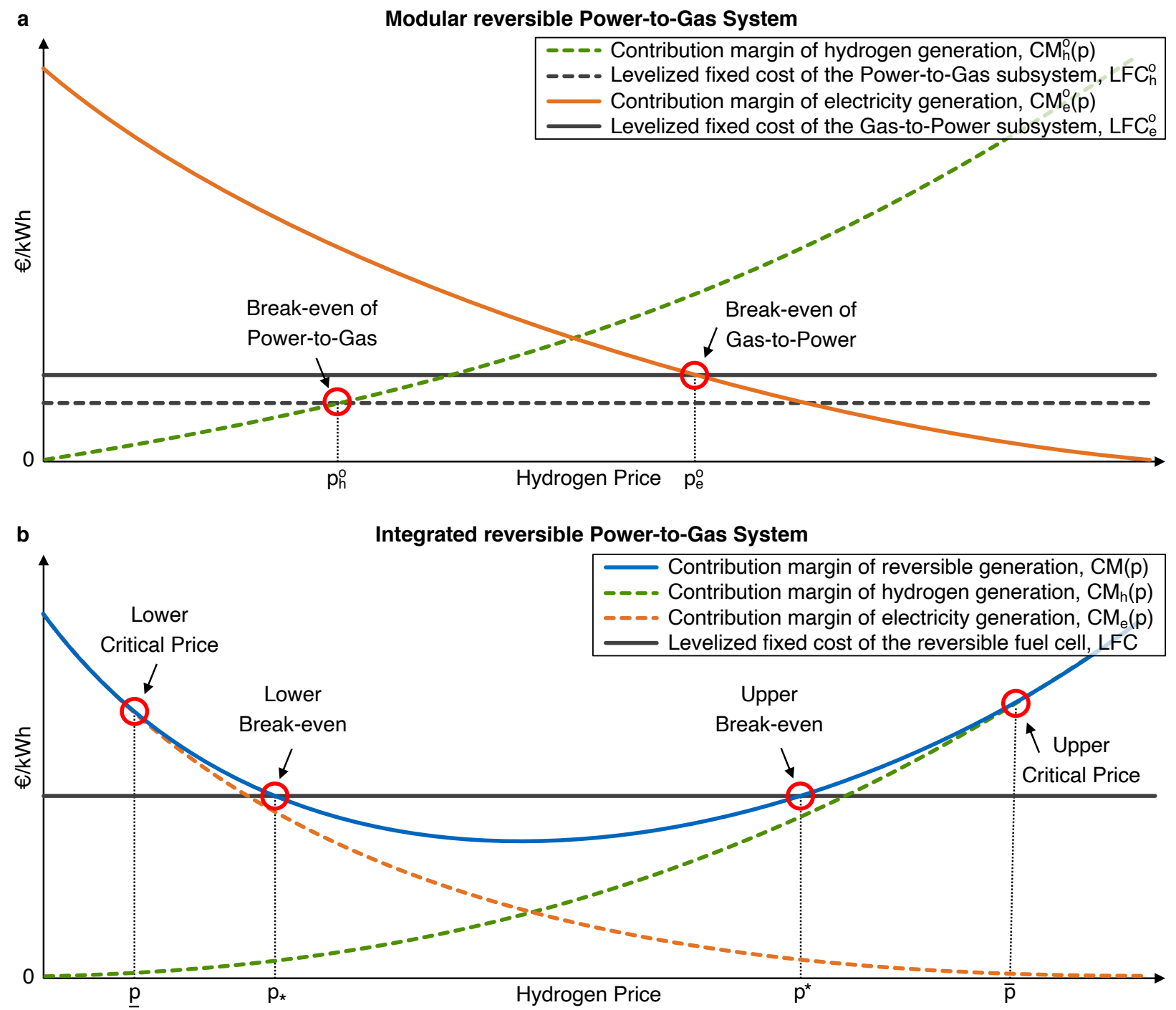

Figure 2. Economics of a reversible Power-to-Gas system. a,b, The figure illustrates the potential cost-competitiveness and value of reversible operation in terms of the respective break-even prices of (a) a modular reversible Power-to-Gas system, and (b) an integrated reversible Power-to-Gas system.

These points are denoted by $p_{*}$ and $p^{*}$, respectively.

To examine the value of reversibility, suppose hypothetically that the integrated system could operate in only one direction. For instance, suppose the system is constrained to only produce hydrogen (i.e., $C F_{e}(t \mid p)$ in (4) is set identically equal to zero). For sufficiently large values of $p$, there then exists a critical value denoted by $\bar{p}$ such that $C M(\bar{p})=C M_{h}(\bar{p})$. This equality holds for all $p \geq \bar{p}$. Conversely, there exists a lower critical price below which only electricity generation would be valuable, that is, $C M(p)=C M_{e}(p)$ for all $p \leq \underline{p}$. 
Finding 2: The integrated reversible PtG system is cost-competitive if and only if the prevailing hydrogen market price, $p$, does not fall into the range $\left[p_{*}, p^{*}\right]$. Reversibility of the integrated system is valuable if and only if either $p \in\left(\underline{p}, p_{*}\right)$ or $p \in\left(p^{*}, \bar{p}\right)$.

Finding 2 shows that an integrated reversible PtG system is cost-competitive if the market price of hydrogen moves either into an upper or lower range relative to the price at which the optimized contribution margin reaches its minimum. For the case where $p \in\left(p^{*}, \bar{p}\right)$, Figure 2b depicts the possibility that the integrated system primarily generates hydrogen, but also operates bi-directionally. Such systems could create an effective buffer against the intermittency of renewables when power is absorbed from the electricity market for hydrogen conversion, yet occasionally electricity is generated at hours of limited power supply and correspondingly high power prices. The range of hydrogen prices at which an integrated system generates both outputs hinges, in addition to cost, on the round-trip efficiency and the volatility in power prices (Figure 1).

An implicit assumption underlying Finding 2 and Figure $2 \mathrm{~b}$ is that $L F C$ exceeds the minimum of the $C M(\cdot)$ curve, for otherwise the break-even prices $p_{*}$ and $p^{*}$ do not exist (we ignore the non-generic scenario in which there is exactly one break-even price at a tangential point). In case $L F C<C M(\cdot)$ for all $p$, the integrated reversible PtG system will always be cost-competitive and reversibility will be of value for all hydrogen prices within the interval $(\underline{p}, \bar{p})$. In this case, the flexibility of the integrated reversible PtG system allows it to compensate for any decline in the prevailing market price of hydrogen by turning to electricity production for a larger share of the available time.

\section{Current Economics of Reversible Power-to-Gas}

To apply the preceding model framework, we calibrate the model parameters in the current market environment of Germany and Texas. Both jurisdictions have recently deployed considerable amounts of renewable energy $\stackrel{34}{34}$. While Germany has maintained coal and natural gas plants as capacity reserves, Texas has retired several conventional generators ${ }^{\sqrt{35}}$. The average wholesale electricity price in 2019 was comparable for both jurisdictions, yet power prices in Texas exhibited much higher volatility. As detailed further in Methods and Supplementary Tables $2-5$, our calculations rely on a range of data sources collected from journal articles, industry data, and publicly available reports. Table 1 summarizes average values of 
key cost and operational parameter estimates.

Table 1. Main input variables.

\begin{tabular}{lcc}
\hline & Germany & Texas \\
\hline Modular Reversible PtG System & & \\
Electrolysis: System price & $1,606 € / \mathrm{kW}$ & $1,799 \$ / \mathrm{kW}$ \\
Electrolysis: Conversion rate to hydrogen & $0.019 \mathrm{~kg} / \mathrm{kWh}$ & $0.019 \mathrm{~kg} / \mathrm{kWh}$ \\
Gas Turbine: System price & $1,000 € / \mathrm{kW}$ & $1,199 \$ / \mathrm{kW}$ \\
Gas Turbine: Conversion rate to electricity & $20.00 \mathrm{kWh} / \mathrm{kg}$ & $20.00 \mathrm{kWh} / \mathrm{kg}$ \\
Useful lifetime & 25 years & 25 years \\
Integrated Reversible PtG System & & \\
System price & $2,243 € / \mathrm{kW}$ & $2,512 \$ / \mathrm{kW}$ \\
Conversion rate to hydrogen & $0.023 \mathrm{~kg} / \mathrm{kWh}$ & $0.023 \mathrm{~kg} / \mathrm{kWh}$ \\
Conversion rate to electricity & $20.00 \mathrm{kWh} / \mathrm{kg}$ & $20.00 \mathrm{kWh} / \mathrm{kg}$ \\
Useful lifetime & 15 years & 15 years \\
Either System & & \\
Average electricity price $(2019)$ & $3.77 € \mathrm{c} / \mathrm{kWh}$ & $3.77 \$ \mathrm{c} / \mathrm{kWh}$ \\
Cost of capital & $4.00 \%$ & $6.00 \%$ \\
\hline
\end{tabular}

Conversion rates are based on original industry data and reflect system-level energy efficiencies that include energy required for maintaining operating temperature. Cost parameters account for economies of scale exhibited by systems of an average size.

Our numbers for the modular PtG system are based on a one-directional PEM electrolyzer and a combined-cycle gas turbine. Recent literature attributes about the same conversion rate to stationary PEM fuel cells as to combined-cycle gas turbines, though the former also entail higher system prices ${ }^{20136}$. For the integrated reversible PtG system, we consider unitized generative SOC fuel cells that are already commercially available $\sqrt{30136}$. Regarding the conversion efficiency, we note that PEM electrolyzers attain a near-constant efficiency beyond a small threshold utilization level $[30$. For integrated PtG systems, we interpret the conversion efficiency parameters identified in the literature (shown in Table 1) as those obtained at full capacity utilization. Thus far, the existing literature provides no evidence on the shape of the functions $\eta_{h}(\cdot)$ and $\eta_{e}(\cdot)$. If these conversion rates were to decrease significantly for capacity utilization values approaching one, our findings regarding the cost competitiveness of integrated reversible PtG systems should be interpreted as a lower bound, because the achievable optimized contribution margins might then be larger for capacity factors strictly less than one. Supplementary Note 2 further examines the sensitivity of our numerical findings to changes in the conversion rates of such systems.

The investing party is assumed to have access to the day-ahead wholesale market for electricity (see Supplementary Note 3 for findings based on the real-time wholesale market 
for electricity). In order to accelerate the transition towards renewable energy, the German government recently decided that electricity purchases for water electrolysis are exempted from certain taxes and fees paid by industrial customers 37 . In Texas, the investing party is assumed to be able to purchase electricity at wholesale prices subject to a markup, as imposed by suppliers like Griddy (see Supplementary Tables 4-5).

We first determine the hydrogen break-even prices. To assess the cost competitiveness of each (sub-)system, we then compare the break-even prices to prevailing transaction prices for hydrogen supply. These values are applicable benchmarks for hydrogen as both an input and an output when the PtG (or GtP) system can be installed nearby a hydrogen or electricity customer. Market prices currently fall into three segments that vary with purity and scale (volume): large-scale supply between $1.5-2.5 € / \mathrm{kg}$, medium-scale between $3.0-4.0 € / \mathrm{kg}$, and small-scale above $4.0 € / \mathrm{kg}^{31}$.

Our calculations yield break-even prices for the modular electrolyzer $\left(p_{h}^{o}\right)$ of $3.29 € / \mathrm{kg}$ in Germany and $2.94 \$ / \mathrm{kg}$ in Texas, while the break-even prices for the modular gas turbine $\left(p_{e}^{o}\right)$ are $0.54 € / \mathrm{kg}$ in Germany and $1.30 \$ / \mathrm{kg}$ in Texas (Table 2, see Supplementary Tables 6-7 for details). The much higher break-even price for the GtP system in Texas must be attributed to the higher volatility in Texas wholesale electricity prices, which in 2019 exceeded 0.15 $\$ c / k W h$ on a regular basis.

Finding 1 implies that modular Power-to-Gas conversion is cost-competitive in both jurisdictions relative to the prices paid for small- and medium-scale hydrogen supply, while the GtP subsystem is not. Furthermore, the reversibility of the modular system cannot be valuable relative to any prevailing market price for hydrogen because $p_{h}^{o}>p_{e}^{o}$ in both jurisdictions. Our results here confirm the commonly held view that one-directional GtP systems are currently not economically viable ${ }^{9119120}$.

Table 2. Current economics.

\begin{tabular}{lcc}
\hline & Germany & Texas \\
\hline Modular Reversible PtG System & & \\
Break-even price of Power-to-Gas: $p_{h}^{o}$ & $3.19 € / \mathrm{kg}$ & $2.86 \$ / \mathrm{kg}$ \\
Break-even price of Gas-to-Power: $p_{e}^{o}$ & $0.54 € / \mathrm{kg}$ & $1.30 \$ / \mathrm{kg}$ \\
Integrated Reversible PtG System & & \\
Upper break-even price: $p^{*}$ & $3.41 € / \mathrm{kg}$ & $2.59 \$ / \mathrm{kg}$ \\
Lower break-even price: $p_{*}$ & $0.02 € / \mathrm{kg}$ & $-0.01 \$ / \mathrm{kg}$ \\
Upper critical price: $\bar{p}$ & $2.43 € / \mathrm{kg}$ & $>5.0 \$ / \mathrm{kg}$ \\
Lower critical price: $\underline{p}$ & $-1.81 € / \mathrm{kg}$ & $0.59 \$ / \mathrm{kg}$ \\
\hline
\end{tabular}


For the integrated system, our calculations yield break-even prices of $0.02 € / \mathrm{kg}$ for $p_{*}$ and $3.41 € / \mathrm{kg}$ for $p^{*}$ in Germany, while the break-even prices in Texas are $-0.01 \$ / \mathrm{kg}$ and $2.59 \$ / \mathrm{kg}$, respectively (Table 2). The substantially smaller $p^{*}$ in Texas reflects the higher volatility in wholesale power prices. By Finding 2, the integrated system is thus cost-competitive when hydrogen is sold to small- and medium-scale customers in Germany. In Texas, cost competitiveness is achieved even relative to a hydrogen price of at least $\$ 2.59$ per $\mathrm{kg}$, a value that is borderline for industrial-scale supply.

Regarding the value of reversibility for the integrated system, our calculations yield upper and lower critical prices $(\underline{p}$ and $\bar{p})$ of $-1.81 € / \mathrm{kg}$ and $2.43 € / \mathrm{kg}$, respectively, in Germany. In Texas, the corresponding values are $0.59 \$ / \mathrm{kg}$ for $\underline{p}$, while $\bar{p}$ exceeds $5.0 \$ / \mathrm{kg}$. Because the hydrogen prices for medium scale supply fall "comfortably" into the range $\left(p^{*}, \bar{p}\right)=(2.59,5.0)$, we conclude that the reversibility of the integrated PtG system is already valuable in the current Texas environment. Contrary to frequently articulated views in the popular press, the generation of electric power from hydrogen is therefore already economical, provided such generation is part of an integrated PtG system that mainly produces hydrogen yet only occasionally operates in the reverse direction to generate electricity. Such systems can therefore be effective in buffering the increasing volatility in power markets resulting from the growing reliance on intermittent renewable energy sources.

Direct comparison of the modular one-sided and the integrated reversible PtG systems shows that the latter is already positioned more competitively despite its substantially higher systems price, as the break-even price of $\$ 2.59$ is below the corresponding $\$ 2.86$ per $\mathrm{kg}$ for the PEM electrolyzer.

\section{Prospects for Reversible Power-to-Gas}

Recent technological progress in reversible PtG systems suggests further improvements in terms of declining system prices and increasing conversion efficiencies $\frac{38}{40}$. System prices of PEM electrolyzers are forecast to decline at an annual rate of $4.77 \%$, while conversion rates are likely to increase linearly to on average $0.023 \mathrm{~kg} / \mathrm{kWh}$ by $2030^{20131 / 41}$. For combined-cycle gas turbines, both of these parameters are expected to remain unchanged.

To assess the cost dynamics of the unitized generative SOC fuel cell, we rely on a handcollected data set of $N=79$ price observations, as described in Methods. We estimate the trajectory of system price by means of a univariate regression covering the years 2000- 
2019. The functional form of the regression is a constant elasticity model of the form: $v(i)=v(0) \cdot \beta^{i}$, with $v(i)$ representing the system price in year $i$. As shown in Figure 3 , the resulting estimate for the annual price decline is $8.95 \%$ ( $\beta=0.9105)$ with a $95 \%$ confidence interval of $\pm 3.20 \%\left(R^{2}=0.27\right)$.

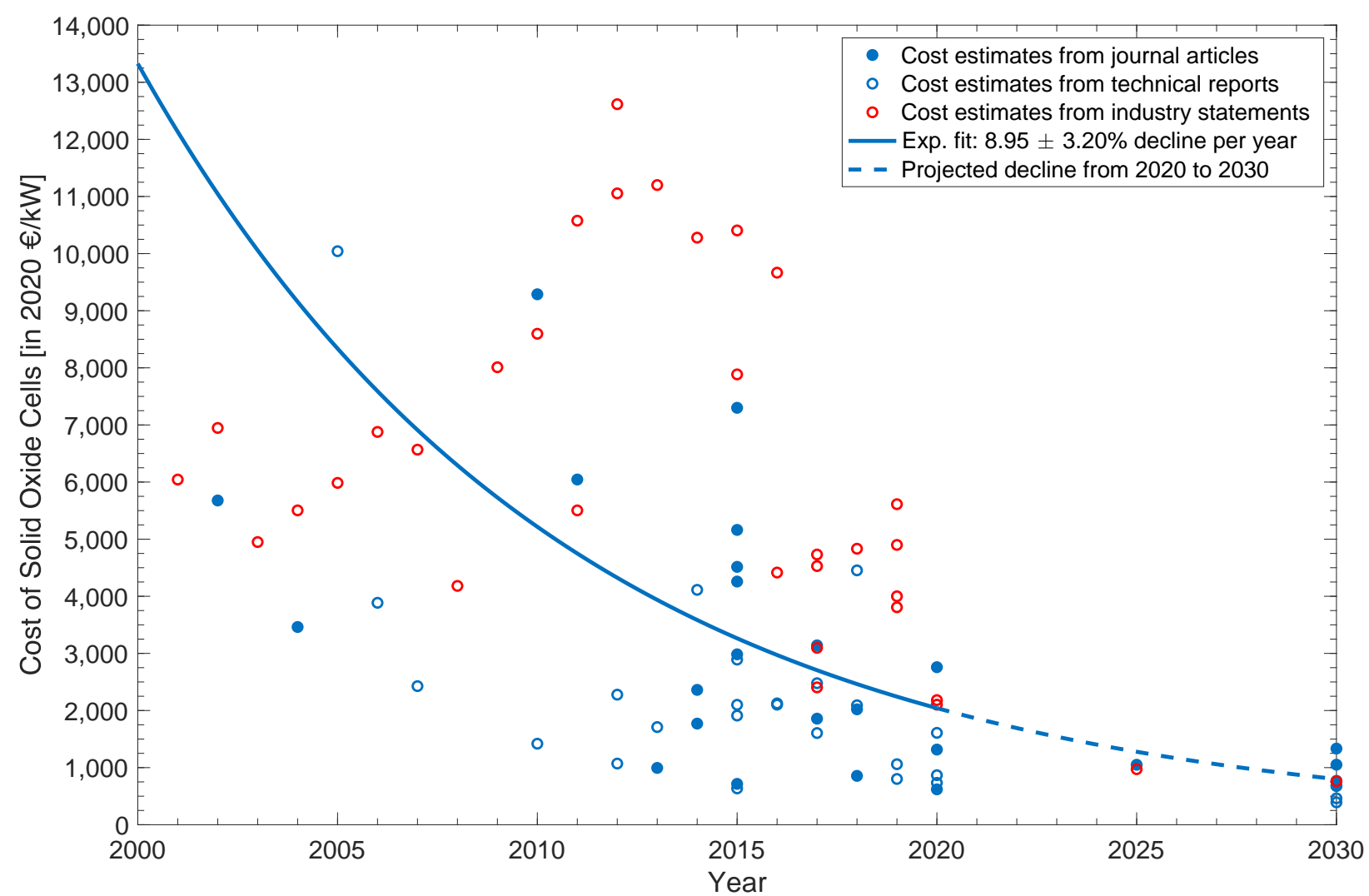

Figure 3. Cost of solid oxide cells. Cost data comes from multiple sources. The univariate regression suggests a constant cost decline over the coming years. The fairly large variance in system prices illustrates the relative novelty of the technology.

The conversion rate of the regenerative SOC fuel cell is expected to increase linearly to on average $0.024 \mathrm{~kg} / \mathrm{kWh}$ for hydrogen generation and $21.67 \mathrm{kWh} / \mathrm{kg}$ for power generation by $2030^{20136}$. Our calculations are based on the current distribution of power prices to isolate the effects of falling system prices and improved conversion rates. A fall in the average of power prices in connection with rising price volatility, as previous studies suggest $\frac{13[14 / 42 / 43}{\text {, }}$ would affect the economics of either system favorably.

Our model results in a trajectory of break-even prices through 2030 as shown in Figure 4 (see Supplementary Tables 8-9 for details). The green lines indicate that the modular electrolyzer is likely to become cost-competitive even relative to the lower prices in the 
large-scale hydrogen market segment. This conclusion emerges sooner in Texas due to higher volatility in power prices. The break-even prices for the modular gas turbine, as depicted by the orange lines, are projected to remain unchanged. Even though the gap between $p_{h}^{o}$ and $p_{e}^{o}$ is shrinking, the reversibility feature of the modular system is unlikely to become valuable during the next decade. This stands in contrast to recent ambitions by gas turbine equipment manufacturers 44,46 .
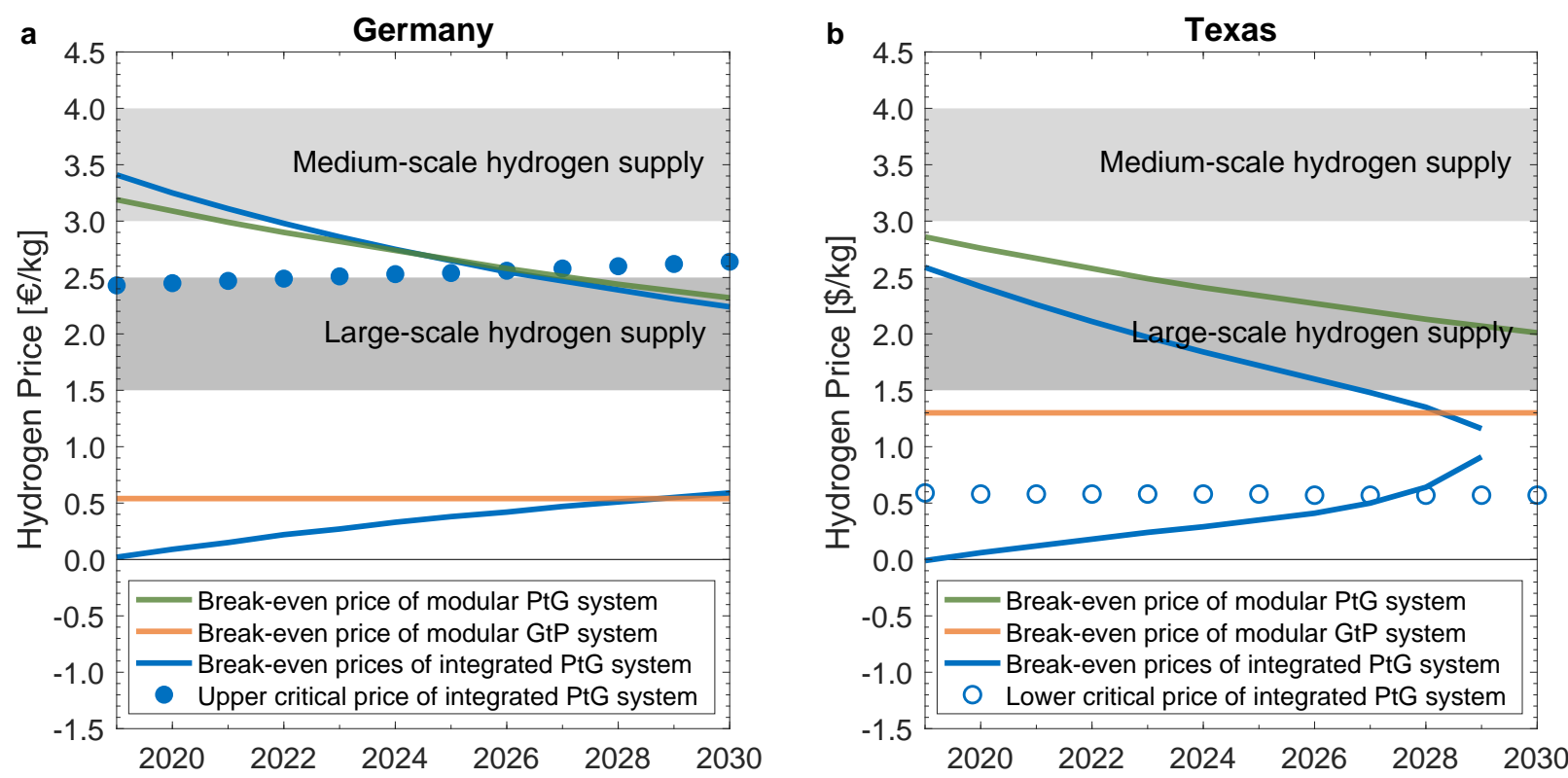

Figure 4. Trajectory of break-even and critical hydrogen prices. a,b, This figure contrasts the relevant hydrogen prices of modular and integrated reversible Power-to-Gas systems in (a) Germany and (b) Texas with the hydrogen prices attained in different market segments. The lower critical price of the integrated system in Germany is consistently below $-1.5 € / \mathrm{kg}$. The upper critical price of the integrated system in Texas is consistently above $5.0 \$ / \mathrm{kg}$.

The integrated system, in contrast, is projected to become widely cost-competitive for large-scale hydrogen supply in both jurisdictions as shown by the upper blue lines in Figure 4. We furthermore project the reversibility feature of the integrated system to become increasingly valuable in both jurisdictions as indicated by the falling upper blue lines. In fact, for Texas the range $\left[p_{*}, p^{*}\right]$ is evaporating within an eight-year time frame. As explained in the modeling section, this projection corresponds to a scenario where the flexibility inherent in the unitized regenerative fuel cell allows it to achieve an optimized contribution that exceeds the levelized fixed cost of the system, regardless of the prevailing hydrogen price.

In Germany, the reversibility feature of the integrated system is likely to deliver value 
starting in the second half of the coming decade. This can be seen in Figure 4 a by comparing the upper blue line with the blue dots, which illustrate the trajectory of the upper critical prices $(\bar{p})$ for the integrated system. The reason is that, as the upper break-even price falls, the reversible PtG system will increasingly switch to power generation, as opposed to staying idle, when electricity prices peak (Figure 1).

\section{Concluding Remarks}

Our analysis has demonstrated that recent advances in unitized regenerative solid oxide fuel cells already make such systems competitive relative to current hydrogen prices. By taking advantage of fluctuations in hourly electricity prices, reversible PtG systems not only act as buffers in electricity markets, they also broaden the supply sources for hydrogen as an industrial input and general energy carrier. If recent trends in the acquisition cost of solid oxide cells continue over the next 5-10 years, our projections indicate that such systems will remain competitive even in the face of substantially lower hydrogen prices, as the electrolyzer then adjusts by operating more frequently as a Gas-to-Power system.

Several promising avenues for future research emerge from our analysis. Earlier work has shown that the economics of electrolyzers can be improved by vertically integrating them with upstream renewable energy sources to achieve operational synergies $\underline{47}$. It remains to be seen to what extent the addition of a renewable power source would improve the capacity utilization of a reversible PtG system and, therefore, lower the corresponding break-even values. Furthermore, if one views a reversible PtG system as an energy storage device, the natural question is how its competitiveness compares to that of other storage technologies, such as batteries or pumped hydro-power systems ${ }^{8 / 9|48| 49}$.

From an industry and policy perspective, we note that the inherent flexibility of integrated reversible PtG systems makes them valuable during periods of electricity scarcity, including regular demand peaks and irregular supply shocks. With increasing penetration levels of renewable energy, this flexibility feature is likely to become more valuable over time. We finally note that our projections regarding the economic positioning of reversible PtG systems in the future have relied on a regression model that presumes that cost declines are a function of calendar time. Yet, the literature on clean energy technologies has shown that cost declines are not merely an exogenous function of time but instead are determined endogenously by the cumulative number of deployments of these systems ${ }^{41}$. Policy-makers should keep these 
long-term benefits in mind in adopting regulatory policies aimed at accelerating the rate of PtG system deployments in the short-run.

\section{Methods}

\section{Techno-Economic Model}

Step 1: Derivation of the Aggregate Contribution Margins

We begin with the derivation of the optimized aggregate contribution margin, $C M(p)$, that is attainable annually if the investor acquires a $1 \mathrm{~kW}$ system of the integrated reversible PtG system and the prevailing market price of hydrogen is $p$. By construction:

$$
\begin{aligned}
& C M(p)=\frac{1}{m} \int_{0}^{m} \max _{C F_{h}, C F_{e}}\{\left.\eta_{h}\left(C F_{h}\right) \cdot p-q(t)-w_{h}\right] \cdot C F_{h} \\
&\left.+\left[q(t)-\frac{p}{\eta_{e}\left(C F_{e}\right)}-w_{e}\right] \cdot C F_{e}\right\} d t
\end{aligned}
$$

subject to $0 \leq C F_{h}, C F_{e} \leq 1$ and the technical constraint that the unitized regenerative fuel cell can only run in one direction at any point in time. It follows that $C M(p)$ is additively separable and can be written as $C M(p)=C M_{h}(p)+C M_{e}(p)$, with:

$$
\begin{aligned}
& C M_{h}(p)=\frac{1}{m} \int_{0}^{m}\left[\eta_{h}\left(C F_{h}^{*}(t \mid p)\right) \cdot p-q(t)-w_{h}\right] \cdot C F_{h}^{*}(t \mid p) d t \\
& C M_{e}(p)=\frac{1}{m} \int_{0}^{m}\left[q(t)-\frac{p}{\eta_{e}\left(C F_{e}^{*}(t \mid p)\right)}-w_{e}\right] \cdot C F_{e}^{*}(t \mid p) d t
\end{aligned}
$$

Here, $C F_{h}^{*}(t \mid p)$ and $C F_{e}^{*}(t \mid p)$ are chosen to maximize $\left[\eta_{h}\left(C F_{h}\right) \cdot p-q(t)-w_{h}\right]$ and $[q(t)-$ $\left.\frac{p}{\eta_{e}\left(C F_{e}\right)}-w_{e}\right]$, respectively, at all points in time $t$.

For the modular reversible PtG systems, the aggregate optimized contribution margins $C M_{h}^{o}(p)$ and $C M_{e}^{o}(p)$ are derived in direct analogy to (6).

Step 2: Convexity of $C M(\cdot)$ in $p$

We demonstrate the convexity of the aggregate annual contribution margin pointwise, that is, convexity holds at any point in time $t$. Specifically, it suffices to show that for any 
$0 \leq \lambda \leq 1$

$$
\begin{aligned}
C M\left(t \mid p_{\lambda}\right) & =A\left(t \mid p_{\lambda}\right) \cdot C F_{h}^{*}\left(t \mid p_{\lambda}\right)+B\left(t \mid p_{\lambda}\right) \cdot C F_{e}^{*}\left(t \mid p_{\lambda}\right) \\
& \leq \lambda\left[A\left(t \mid p^{1}\right) \cdot C F_{h}^{*}\left(t \mid p^{1}\right)+B\left(t \mid p^{1}\right) \cdot C F_{e}^{*}\left(t \mid p^{1}\right)\right] \\
& +(1-\lambda)\left[A\left(t \mid p^{0}\right) \cdot C F_{h}^{*}\left(t \mid p^{0}\right)+B\left(t \mid p^{0}\right) \cdot C F_{e}^{*}\left(t \mid p^{0}\right)\right] \\
& =\lambda \cdot C M\left(t \mid p^{1}\right)+(1-\lambda) \cdot C M\left(t \mid p^{o}\right),
\end{aligned}
$$

where $p_{\lambda} \equiv \lambda \cdot p^{1}+(1-\lambda) \cdot p^{0}, A(t \mid p) \equiv \eta_{h}\left(C F_{h}^{*}(t \mid p)\right) \cdot p-q(t)-w_{h}$ and $B(t \mid p) \equiv$ $q(t)-\frac{p}{\eta_{e}\left(C F_{e}^{*}(t \mid p)\right)}-w_{e}$. As noted above, for any $p$, either $A(t \mid p) \leq 0$ or $B(t \mid p) \leq 0$ because $\eta_{h}(\cdot) \cdot \eta_{e}(\cdot) \leq 1$.

Suppose now, without loss of generality, that $A\left(t \mid p_{\lambda}\right)>0$ in which case the left-hand side of the preceding inequality is equal to $A\left(t \mid p_{\lambda}\right)$. Finally, the right-hand side of the above inequality is given by:

$$
\lambda \cdot \max \left\{A\left(t \mid p^{1}\right), B\left(t \mid p^{1}\right), 0\right\}+(1-\lambda) \cdot \max \left\{A\left(t \mid p^{0}\right), B\left(t \mid p^{0}\right), 0\right\} .
$$

By construction, this last expression is at least as large as $\lambda \cdot A\left(t \mid p^{1}\right)+(1-\lambda) \cdot A\left(t \mid p^{0}\right)$, which, because of the linearity of $A(t \mid \cdot)$ in $p$, is equal to $A\left(t \mid p_{\lambda}\right)$, thus establishing the desired inequality. The claim regarding convexity of $C M(\cdot)$ then follows from the observation that the sum (integral) of convex functions is also convex.

\section{Step 3: Net-Present Value of the Reversible PtG Systems}

As in the previous steps, we focus on integrated reversible PtG systems, with the derivation for modular systems being entirely analogous. The levelized fixed cost of the system, LFC, aggregates all fixed expenditures required over the life of the reversible PtG system. This aggregate expenditure is then divided by $L$, the levelization factor that expresses the discounted number of hours that the capacity is available over its lifetime. The resulting cost is then a unit cost per hour of operation. Formally:

$$
L F C=f+\Delta \cdot c .
$$

Here, $f$ represents the levelized value of fixed operating costs, $c$ represents the levelized capacity cost per $\mathrm{kWh}$, and $\Delta$ captures the impact of income taxes and the depreciation tax shield. Denoting by $v$ the system price of the regenerative fuel cell per $\mathrm{kW}$ of peak electricity 
absorption and desorption, we have:

$$
c=\frac{v}{L}
$$

with the levelization factor calculated as:

$$
L=m \cdot \sum_{i=1}^{T} \gamma^{i} \cdot x^{i-1}
$$

Here, $m$ denotes the number of hours per year, that is, $m=8,760$ and the parameter $T$ represents the number of years of useful economic life of the system. Since capacity may degrade over time, we denote by $x$ the degradation factor so that $x^{i-1}$ gives the fraction of the initial capacity that is functioning in year $i$. The parameter $\gamma=(1+r)^{-1}$ and represents the discount factor with $r$ as the cost of capital. This interest rate should be interpreted as the weighted average cost of capital if the levelized cost is to incorporate returns for both equity and debt investors 50 .

Similarly, the levelized fixed operating cost per kWh similarly comprises the total discounted fixed operating cost incurred over the lifetime of the system.

$$
f=\frac{\sum_{i=1}^{T} F_{i} \cdot \gamma^{i}}{L} .
$$

The cost of capacity is affected by corporate income taxes through a debt and a depreciation tax shield, as interest payments on debt and depreciation charges reduce the taxable earnings of a firm. The debt tax shield is included in the calculation if $r$ is interpreted as the weighted average cost of capital. Let $d_{i}$ denote the allowable tax depreciation charge in year $i$. Since the assumed lifetime for tax purposes is usually shorter than the actual economic lifetime, we set $d_{i}=0$ in those years. If $\alpha$ represents the effective corporate income tax rate, the tax factor is given by:

$$
\Delta=\frac{1-\alpha \cdot \sum_{i=1}^{T} d_{i} \cdot \gamma^{i}}{1-\alpha} .
$$

The formal claim then is that the net-present value of an investment in one $\mathrm{kW}$ of the integrated reversible PtG system is given by:

$$
N P V(p)=(1-\alpha) \cdot L \cdot[C M(p)-L F C] .
$$


This relation is readily verified by noting that the after-tax cash flows in year $i$ is:

$$
C F L_{i}(p)=x^{i-1} \cdot \int_{0}^{m} C M(t \mid p) d t-F_{i}-\alpha \cdot I_{i}(p),
$$

where $I_{i}(p)$ denotes the taxable income in year $i$. Specifically:

$$
I_{i}(p)=x^{i-1} \cdot \int_{0}^{m} C M(t \mid p) d t-F_{i}-v \cdot d_{i} .
$$

Since $C F L_{0}=-v$, the discounted value of all after-tax cash flows is indeed equal to the expression in $(13)$. Similar reasoning yields that the unit net-present values of the modular PtG and GtP systems are, respectively, given by:

$$
N P V_{h}(p)=(1-\alpha) \cdot L \cdot\left[C M_{h}^{o}(p)-L F C_{h}^{o}\right]
$$

and

$$
N P V_{e}(p)=(1-\alpha) \cdot L \cdot\left[C M_{e}^{o}(p)-L F C_{e}^{o}\right]
$$

\section{Cost Dynamics of Solid Oxide Cells}

We collected cost estimates from a range of information sources, including industry publications, academic articles in peer-reviewed journals and technical reports by agencies, consultancies and analysts. These documents were retrieved by searching the database Scopus and the web with Google's search engine using a combination of one of the five technologyspecific keywords 'reversible electrolyzer', 'reversible fuel cell', 'solid oxide electrolysis cell', 'solid oxide fuel cell', or 'reversible power-to-gas' with the two economic keywords 'cost' and 'investment'. For industry statements, we also searched with the name of a manufacturer in combination with the economic keywords. For the Google search, we reviewed the top 100 search results. The review and the data set is documented in an Excel file available as part of the Supplemental Data.

The review yielded 211 sources, which we filtered by several criteria to ensure quality and timeliness. First, we excluded results published before the year 2000 and, for journal articles, results published in a journal with a rank below 0.5 in the Scimago Journal and Country Rank. The threshold of 0.5 showed to be effective for excluding articles published, for instance, in conference proceedings without peer-review. As for technical reports, we only 
included results that could convince through appearance, writing, clarity of methodology, and reputation of the author(s) or authoring organization(s). These measures removed 47 sources. Reviewing the resulting stock of sources, we further excluded sources that did not provide direct cost or efficiency data (49) and sources citing other articles as original sources (29). These citations were traced back to the original source. If the original was new, we added it to the pool. We further added sources that we found with a previous review ${ }^{31}$ and that were new to the pool.

Our procedure left 86 sources with original data from industry or an original review of multiple sources and yielded 89 cost estimates. In case the sources issued range estimates, we took the arithmetic mean of the highest and the lowest value. The common currency is Euro and all data points in other currencies were converted using the average exchange rate of the respective year as provided by the European Central Bank. Regarding inflation, all historic cost estimates were adjusted using the HCPI of the Euro Zone as provided by the European Central Bank. The cost estimates were winsorized at a $1.0 \%$ level. Figure 3 in the main body shows the cost estimates and regression results.

\section{Data availability}

The data used in this study are referenced in the main body of the paper and the Supplemental Information. Data that generated the plots in the paper are provided in the Supplemental Information. Additional data and information is available from the corresponding author upon reasonable request.

\section{References}

[1] Davis, S. J. et al. Net-zero emissions energy systems. Science 9793 (2018).

[2] Olauson, J. et al. Net load variability in the Nordic countries with a highly or fully renewable power system. Nature Energy 1, 1-14 (2016).

[3] Sternberg, A. et al. Power-to-What? Environmental assessment of energy storage systems. Energy and Environmental Science 8, 389-400 (2015).

[4] Comello, S. \& Reichelstein, S. The emergence of cost effective battery storage. Nature Communications 10, 2038 (2019). 
[5] Shaner, M. R., Atwater, H. A., Lewis, N. S. \& McFarland, E. W. A comparative technoeconomic analysis of renewable hydrogen production using solar energy. Energy and Environmental Science 9, 2354-2371 (2016).

[6] Van Vuuren, D. P. et al. Alternative pathways to the $1.5 \mathrm{C}$ target reduce the need for negative emission technologies. Nature Climate Change 8, 391-397 (2018).

[7] Parkinson, B., Balcombe, P., Speirs, J. F., Hawkes, A. D. \& Hellgardt, K. Levelized cost of CO2 mitigation from hydrogen production routes. Energy and Environmental Science 12, 19-40 (2019).

[8] Arbabzadeh, M., Sioshansi, R., Johnson, J. X. \& Keoleian, G. A. The role of energy storage in deep decarbonization of electricity production. Nature Communications 10 (2019).

[9] Sepulveda, N. A., Jenkins, J. D., Edington, A., Mallapragada, D. S. \& Lester, R. K. The design space for long-duration energy storage in decarbonized power systems. Nature Energy (2021).

[10] Hauch, A. et al. Recent advances in solid oxide cell technology for electrolysis. Science $\mathbf{3 7 0}$ (2020).

[11] van Renssen, S. The hydrogen solution? Nature Climate Change 10, 799-801 (2020).

[12] Ueckerdt, F. et al. Potential and risks of hydrogen-based e-fuels in climate change mitigation. Nature Climate Change (2021).

[13] Wozabal, D., Graf, C. \& Hirschmann, D. The effect of intermittent renewables on the electricity price variance. OR Spectrum 38, 687-709 (2016).

[14] Ketterer, J. C. The impact of wind power generation on the electricity price in Germany. Energy Economics 44, 270-280 (2014).

[15] Guerra, O. J. et al. The value of seasonal energy storage technologies for the integration of wind and solar power. Energy and Environmental Science (2020).

[16] Staffell, I. et al. The role of hydrogen and fuel cells in the global energy system. Energy and Environmental Science 12, 463-491 (2019).

[17] Guerra, O. J., Eichman, J., Kurtz, J. \& Hodge, B. M. Cost Competitiveness of Electrolytic Hydrogen. Joule 3, 2425-2443 (2019).

[18] Rau, G. H., Willauer, H. D. \& Ren, Z. J. The global potential for converting renewable electricity to negative-CO2-emissions hydrogen. Nature Climate Change 8, 621-626 (2018). 
[19] Braff, W. A., Mueller, J. M. \& Trancik, J. E. Value of storage technologies for wind and solar energy. Nature Climate Change 6, 964-969 (2016).

[20] IEA. The Future of Hydrogen. Tech. Rep. (2019).

[21] Ding, H. et al. Self-sustainable protonic ceramic electrochemical cells using a triple conducting electrode for hydrogen and power production. Nature Communications 11 (2020).

[22] Regmi, Y. N. et al. A low temperature unitized regenerative fuel cell realizing $60 \%$ round trip efficiency and 10000 cycles of durability for energy storage applications. Energy and Environmental Science (2020).

[23] Elcogen. Reversible solid oxide cell technology as a power storing solution for renewable energy (Italy) (2018). URL http://bit.1y/385mR4N.

[24] Schmidt, O. et al. Projecting the Future Levelized Cost of Electricity Storage Technologies. Joule 1-20 (2019).

[25] Proost, J. State-of-the art CAPEX data for water electrolysers, and their impact on renewable hydrogen price settings. International Journal of Hydrogen Energy 44, 4406-4413 (2019).

[26] Pellow, M. A., Emmott, C. J., Barnhart, C. J. \& Benson, S. M. Hydrogen or batteries for grid storage? A net energy analysis. Energy and Environmental Science 8, 1938-1952 (2015).

[27] Mogensen, M. B. et al. Reversible solid-oxide cells for clean and sustainable energy. Clean Energy 3, 175-201 (2019).

[28] Peng, X. et al. Hierarchical electrode design of highly efficient and stable unitized regenerative fuel cells (URFCs) for long-term energy storage. Energy and Environmental Science 13, 48724881 (2020).

[29] Graves, C., Ebbesen, S. D., Mogensen, M. \& Lackner, K. S. Sustainable hydrocarbon fuels by recycling $\mathrm{CO} 2$ and $\mathrm{H} 2 \mathrm{O}$ with renewable or nuclear energy. Renewable and Sustainable Energy Reviews 15, 1-23 (2011).

[30] Buttler, A. \& Spliethoff, H. Current status of water electrolysis for energy storage, grid balancing and sector coupling via power-to-gas and power-to-liquids: A review. Renewable and Sustainable Energy Reviews 82, 2440-2454 (2018).

[31] Glenk, G. \& Reichelstein, S. Economics of Converting Renewable Power to Hydrogen. Nature Energy 4, 216-222 (2019).

[32] Reichelstein, S. \& Rohlfing-Bastian, A. Levelized Product Cost: Concept and decision relevance. The Accounting Review 90, 1653-1682 (2015). 
[33] MIT. The Future of Coal: Options for a Carbon-Constrained World. Tech. Rep. (2007).

[34] International Energy Agency. CO2 Emissions from Fuel Combustion 2017 - Highlights. Tech. Rep. (2017).

[35] Reuters. Texas power prices jump to record high as heat bakes state (2019). URL https: //reut.rs/2tw4h78.

[36] Weidner, E., Ortiz Cebolla, R. \& Davies, J. Global deployment of large capacity stationary fuel cells. Tech. Rep. (2019).

[37] Bundesrat. 383/19 Gesetz zur Änderung des Gesetzes über Energiedienstleistungen und andere Energieeffizienzmaßnahmen (2019). URL https : //www . bundesrat.de/bv .html?id=0383-19.

[38] Rivera-Tinoco, R., Schoots, K. \& Van Der Zwaan, B. Learning curves for solid oxide fuel cells. Energy Conversion and Management 57, 86-96 (2012).

[39] Wei, M., Smith, S. J. \& Sohn, M. D. Experience curve development and cost reduction disaggregation for fuel cell markets in Japan and the US. Applied Energy 191, 346-357 (2017).

[40] Saba, S. M., Müller, M., Robinius, M. \& Stolten, D. The investment costs of electrolysis A comparison of cost studies from the past 30 years. International Journal of Hydrogen Energy 43, 1209-1223 (2018).

[41] Glenk, G., Meier, R. \& Reichelstein, S. Cost Dynamics of Clean Energy Technologies (2021).

[42] Paraschiv, F., Erni, D. \& Pietsch, R. The impact of renewable energies on EEX day-ahead electricity prices. Energy Policy 73, 196-210 (2014).

[43] Kök, A. G., Shang, K. \& Yücel, S. Impact of Electricity Pricing Policies on Renewable Energy Investments and Carbon Emissions. Management Science 64, 131-148 (2018).

[44] Uniper SE. Siemens und Uniper bündeln Kräfte bei Dekarbonisierung der Stromerzeugung (2020). URL https://bit.ly/3iuJ0lm.

[45] Businesswire. Mitsubishi Power Cuts Through the Complexity of Decarbonization: Offers the World's First Green Hydrogen Standard Packages for Power Balancing and Energy Storage (2020).

[46] General Electric. Hydrogen for power generation. Tech. Rep. (2021).

[47] Glenk, G. \& Reichelstein, S. Synergistic Value in Vertically Integrated Power-to-Gas Energy Systems. Production and Operations Management 29, 526-546 (2020). 
[48] Albertus, P., Manser, J. S. \& Litzelman, S. Long-Duration Electricity Storage Applications, Economics, and Technologies. Joule 4, 21-32 (2020).

[49] Baumgarte, F., Glenk, G. \& Rieger, A. Business Models and Profitability of Energy Storage. iScience 23, 101554 (2020).

[50] Ross, S. A., Westerfield, R. \& Jordan, B. D. Fundamentals of corporate finance (Tata McGrawHill Education, 2008).

\section{Acknowledgments}

We gratefully acknowledge financial support through the Deutsche Forschungsgemeinschaft (DFG, German Research Foundation) - Project-ID 403041268 - TRR 266. This research was also supported by the Joachim Herz Stiftung and the Hanns-Seidel-Stiftung with funds from the Federal Ministry of Education and Research of Germany. Helpful comments were provided by Stefanie Burgahn, Céleste Chevalier, Stephen Comello, Gunther Friedl, Rebecca Meier, Christian Stoll, Nikolas Wölfing, and colleagues at the Massachusetts Institute of Technology, the University of Mannheim, and the Technical University of Munich. Finally, we thank Lisa Fuhrmann for providing valuable assistance with the data collection.

\section{Author contributions}

G.G. initiated the research question and the techno-economic model. He also conducted the literature review, the data collection and the numerical calculations. The authors jointly analyzed the economic model and both contributed to the writing of the paper.

\section{Conflicts of interest}

The authors declare no competing financial or non-financial interests. 


\section{Supplementary Information to "Energy Conversion and Storage: The Value of Reversible Power-to-Gas Systems"}

Gunther Glenk, University of Mannheim and Massachusetts Institute of Technology,

Stefan Reichelstein, University of Mannheim, Stanford University, and Leibniz Centre for European Economic Research (ZEW)

Supplementary Table 1. List of symbols and acronyms.

\begin{tabular}{llll}
\hline$\alpha$ & Effective corporate income tax rate & $\mathrm{kW}$ & Kilowatt \\
$c$ & Cost of capacity per hour & $\mathrm{kWh}$ & Kilowatt hour \\
$C F(t)$ & Capacity factor at time $t$ & $L$ & Levelization factor \\
$C F L_{i}$ & After-tax cash flow in year $i$ & $\mathrm{LFC}$ & Levelized fixed cost \\
$C M(t)$ & Contribution margin at time $t$ & $m$ & Number of hours per year \\
$\Delta$ & Tax factor & $\mu(t)$ & Deviation factor of prices \\
$d_{i}$ & Allowable tax depreciation in year $i$ & $p$ & Hydrogen price \\
$\epsilon(t)$ & Deviation factor of generation & $\mathrm{PEM}$ & Polymer electrolyte membrane \\
$\eta_{h}$ & Conversion rate from electricity to hydrogen & $\mathrm{PtG}$ & Power-to-Gas \\
$\eta_{e}$ & Conversion rate from hydrogen to electricity & $q(t)$ & Electricity price at time $t$ \\
$f$ & Fixed operating cost per hour & $r$ & Cost of capital \\
$F_{i}$ & Fixed operating cost in year $i$ & $\mathrm{SOC}$ & Solide oxide cell \\
$\gamma$ & Discount factor & $t$ & Hour within year $i$ \\
$\Gamma$ & Co-variation coefficient & $T$ & Useful life of capacity investment \\
$\mathrm{GtP}$ & Gas-to-Power & $v$ & System price of capacity \\
$I_{i}$ & Taxable income in year $i$ & $w$ & Variable cost markup per kWh \\
$\mathrm{kg}$ & Kilogram & $x$ & Annual degradation rate of capacity \\
\hline
\end{tabular}

Supplementary Table 2. Input variables for modular reversible Power-to-Gas.

\begin{tabular}{|c|c|c|c|}
\hline Input Variable & Germany & Texas & Source \\
\hline \multicolumn{4}{|l|}{ Electrolysis } \\
\hline System price, $v_{h}^{o}$ & $1,606 € / \mathrm{kW}$ & $1,799 \$ / \mathrm{kW}$ & Ref.1] \\
\hline Fixed operating cost, $F_{b}^{o}$ & $48.18 € / \mathrm{kW}$ & $53.96 \$ / \mathrm{kW}$ & Ref.1 \\
\hline Conversion rate to hydrogen, $\eta_{h}^{o}$ & $0.019 \mathrm{~kg} / \mathrm{kWh}$ & $0.019 \mathrm{~kg} / \mathrm{kWh}$ & Ref.1] \\
\hline \multicolumn{4}{|l|}{ Gas Turbine } \\
\hline System price, $v_{e}^{o}$ & $1,000 € / \mathrm{kW}$ & $1,199 \$ / \mathrm{kW}$ & Ref.2 \\
\hline Fixed operating cost, $F_{e i}^{o}$ & $30.00 € / \mathrm{kW}$ & $33.60 \$ / \mathrm{kW}$ & Ref.2] \\
\hline Conversion rate to electricity, $\eta_{e}^{o}$ & $20.00 \mathrm{kWh} / \mathrm{kg}$ & $20.00 \mathrm{kWh} / \mathrm{kg}$ & Ref.2 \\
\hline \multicolumn{4}{|l|}{ Either subsystem } \\
\hline Economic lifetime, $T^{o}$ & 25 years & 25 years & Ref. $[3$ \\
\hline Corporate income tax rate, $\alpha^{o}$ & $30.00 \%$ & $21.00 \%$ & German and U.S. Tax Code \\
\hline Degradation rate, $x^{o}$ & $0.08 \%$ & $0.08 \%$ & Ref. 4 [4 \\
\hline Depreciation rate, $d_{i}^{o}$ & $6.25 \%$ (16y linear) & $100 \%$ Bonus & Ref.5[6] \\
\hline Cost of capital, $r^{o}$ & $4.00 \%$ & $6.00 \%$ & Ref. 78 \\
\hline Electricity market price (2019), $q$ & $3.77 € \mathrm{c} / \mathrm{kWh}$ & $3.77 \$ c / k W h$ & Www.eex.com www.ercot.com \\
\hline $\begin{array}{l}\text { Cost markup for } \\
\text { electricity generation, } w_{e}^{o}\end{array}$ & $0.00 € c / \mathrm{kWh}$ & $0.00 \$ c / \mathrm{kWh}$ & Hydrogen price includes supply \\
\hline $\begin{array}{l}\text { Cost markup for } \\
\text { hydrogen generation, } w_{h}^{o}\end{array}$ & $0.38 € c / \mathrm{kWh}$ & $1.00 \$ \mathrm{c} / \mathrm{kWh}$ & See Supplementary Table $4-5$ \\
\hline
\end{tabular}


Supplementary Table 3. Input variables for integrated reversible Power-to-Gas.

\begin{tabular}{|c|c|c|c|}
\hline Input Variable & Germany & Texas & Source \\
\hline System price, $v$ & $2,243 € / \mathrm{kW}$ & $2,512 \$ / \mathrm{kW}$ & Own review, see Methods \\
\hline Fixed operating cost, $F$ & $67.29 € / \mathrm{kW}$ & $75.36 \$ / \mathrm{kW}$ & Own review, see Methods \\
\hline Conversion rate to hydrogen, $\eta_{h}$ & $0.023 \mathrm{~kg} / \mathrm{kWh}$ & $0.023 \mathrm{~kg} / \mathrm{kWh}$ & Ref.219.11 \\
\hline Conversion rate to electricity, $\eta_{e}$ & $20.00 \mathrm{kWh} / \mathrm{kg}$ & $20.00 \mathrm{kWh} / \mathrm{kg}$ & Ref. 2 |9|12 13 \\
\hline Economic lifetime, $T$ & 15 years & 15 years & Ref.13 \\
\hline Corporate income tax rate, $\alpha$ & $30.00 \%$ & $21.00 \%$ & German and U.S. Tax Code \\
\hline Degradation rate, $x$ & $1.60 \%$ & $1.60 \%$ & Ref. 12 \\
\hline Depreciation rate, $d_{i}$ & $6.25 \%$ (16y linear) & $100 \%$ Bonus & Ref.5[6 \\
\hline Cost of capital, $r$ & $4.00 \%$ & $6.00 \%$ & Ref. $7 / 8$ \\
\hline Electricity market price $(2019), q$ & $3.77 € \mathrm{c} / \mathrm{kWh}$ & $3.77 \$ c / \mathrm{kWh}$ & Www.eex.com www.ercot.com \\
\hline $\begin{array}{l}\text { Cost markup for } \\
\text { electricity generation, } w_{e}\end{array}$ & $0.00 € \mathrm{c} / \mathrm{kWh}$ & $0.00 \$ c / k W h$ & Hydrogen price includes supply \\
\hline $\begin{array}{l}\text { Cost markup for } \\
\text { hydrogen generation, } w_{h}\end{array}$ & $0.42 € c / \mathrm{kWh}$ & $1.05 \$ \mathrm{c} / \mathrm{kWh}$ & See Supplementary Table $4-5$ \\
\hline
\end{tabular}

\section{Supplementary Table 4. Cost markup for hydrogen generation, Germany}

\begin{tabular}{lll}
\hline Variable & Value & Source \\
\hline Electricity price markup & & \\
Transmission charge $(€ c / \mathrm{kWh})$ & 0.000 & $\S 118(6)$ Energiewirtschaftsgesetz \\
Concession charge $(€ c / \mathrm{kWh})$ & 0.000 & $\S 118(6)$ Energiewirtschaftsgesetz \\
EEG levy $(€ c / \mathrm{kWh})$ & 0.100 & $\S 64(2)$ with A. 4 Erneuerbare-Energien-Gesetz \\
CHP levy $(€ c / \mathrm{kWh})$ & 0.030 & $\S 27(1)$ Kraft-Wärme-Kopplungsgesetz \\
$\S 19$ StromNEV levy $(€ c / \mathrm{kWh})$ & 0.025 & $\S 19(2)$ Stromnetzentgeltverordnung \\
Offshore liability levy $(€ c / \mathrm{kWh})$ & 0.030 & $\S 17 \mathrm{f}(5)$ Energiewirtschaftsgesetz \\
Levy for interruptable loads $(€ c / \mathrm{kWh})$ & 0.000 & $\S 18$ Verordnung zu abschaltbaren Lasten \\
Electricity tax $(€ c / \mathrm{kWh})$ & 0.000 & $\S 9 \mathrm{a}(1)$ 1. Stromsteuergesetz \\
Total electricity price markup $(€ c / \mathrm{kWh})$ & 0.185 & \\
& & \\
Other variable cost & & \\
Cost for water and other consumables $(€ / \mathrm{kg})$ & 0.100 & Estimation \\
\hline
\end{tabular}

\section{Supplementary Table 5. Cost markup for hydrogen generation, Texas}

\begin{tabular}{|c|c|c|}
\hline Variable & Value & Source \\
\hline \multicolumn{3}{|l|}{ Electricity price markup } \\
\hline Transmission and distribution charges $(\$ c / k W h)$ & 0.0077 & Ref. 14 , transmission rate \\
\hline Transmission system charge $(\$ c / \mathrm{kWh})$ & 0.3055 & Ref.14, transmission rate \\
\hline Distribution system charge $(\$ c / \mathrm{kWh})$ & 0.0668 & Ref.14, transmission rate \\
\hline System benefit fund charge $(\$ c / \mathrm{kWh})$ & 0.0000 & Ref.14, Rider SBF \\
\hline Transition charge $(\$ c / \mathrm{kWh})$ & 0.0000 & Ref.14, Schedules TC \\
\hline Nuclear decommissioning charge $(\$ c / k W h)$ & 0.0001 & Ref.14, Rider NDC \\
\hline Transmission cost recovery factor $(\$ c / k W h)$ & 0.3094 & Ref.14, Rider TCRF \\
\hline Competition transition charge $(\$ c / \mathrm{kWh})$ & 0.0000 & Ref.14, Rider CTC \\
\hline Competitive metering credit $(\$ c / \mathrm{kWh})$ & 0.0001 & Ref.14, Rider CMC \\
\hline Other charges or credits $(\$ c / \mathrm{kWh})$ & 0.0731 & Ref.14, Riders RCE, EECRF, DCRF \\
\hline Griddy membership fee $(\$ c / \mathrm{kWh})$ & 0.0001 & Ref. 15 \\
\hline Taxes $(\$ c / k W h)$ & 0.0192 & U.S. Tax Code \\
\hline Total electricity price markup $(\$ c / \mathrm{kWh})$ & 0.7880 & \\
\hline \multicolumn{3}{|l|}{ Other variable cost } \\
\hline Cost for water and other consumables $(\$ / \mathrm{kg})$ & 0.1120 & $\begin{array}{l}\text { Conversion of } € \text { value to } \$ \\
\text { with avg. exchange rate of } 2019\end{array}$ \\
\hline
\end{tabular}


Supplementary Table 6. Current economics of modular reversible Power-to-Gas.

\begin{tabular}{|c|c|c|}
\hline & Germany & Texas \\
\hline \multicolumn{3}{|l|}{ Power-to-Gas Subsystem } \\
\hline Contribution margin of hydrogen $C M_{h}^{o}\left(p_{h}^{o}\right)$ & $2.04 € \mathrm{c} / \mathrm{kWh}$ & $2.18 \$ \mathrm{c} / \mathrm{kWh}$ \\
\hline Break-even price for hydrogen, $p_{h}^{o}$ & $3.19 € / \mathrm{kg}$ & $2.86 \$ / \mathrm{kg}$ \\
\hline Capacity factor for hydrogen, $C F_{h}^{o}\left(p_{h}^{o}\right)$ & 0.95 & 0.93 \\
\hline Levelized fixed cost, $L F C_{h}^{o}$ & $2.03 € c / \mathrm{kWh}$ & $2.17 \$ \mathrm{c} / \mathrm{kWh}$ \\
\hline Levelized fixed operating cost, $f_{h}^{o}$ & $0.60 € \mathrm{c} / \mathrm{kWh}$ & $0.67 \$ c / k W h$ \\
\hline Levelized capacity cost, $c_{h}^{o}$ & $1.28 € \mathrm{c} / \mathrm{kWh}$ & $1.74 \$ \mathrm{c} / \mathrm{kWh}$ \\
\hline Tax factor, $\Delta_{h}^{o}$ & 1.12 & 0.86 \\
\hline \multicolumn{3}{|l|}{ Gas-to-Power Subsystem } \\
\hline Contribution margin of electricity, $C M_{e}^{o}\left(p_{e}^{o}\right)$ & $1.28 € \mathrm{c} / \mathrm{kWh}$ & $1.35 \$ \mathrm{c} / \mathrm{kWh}$ \\
\hline Break-even price for hydrogen, $p_{e}^{o}$ & $0.54 € / \mathrm{kg}$ & $1.30 \$ / \mathrm{kg}$ \\
\hline Capacity factor for electricity, $C F_{e}^{o}\left(p_{e}^{o}\right)$ & 0.86 & 0.04 \\
\hline Levelized fixed cost, $L F C_{e}^{o}$ & $1.26 € \mathrm{c} / \mathrm{kWh}$ & $1.35 \$ \mathrm{c} / \mathrm{kWh}$ \\
\hline Levelized fixed operating cost, $f_{e}^{o}$ & $0.37 € \mathrm{c} / \mathrm{kWh}$ & $0.42 \$ c / k W h$ \\
\hline Levelized capacity cost, $c_{e}^{o}$ & $0.80 € c / \mathrm{kWh}$ & $1.08 \$ \mathrm{c} / \mathrm{kWh}$ \\
\hline Tax factor, $\Delta_{e}^{o}$ & 1.12 & 0.86 \\
\hline
\end{tabular}

Supplementary Table 7. Current economics of integrated reversible Power-to-Gas.

\begin{tabular}{|c|c|c|}
\hline & Germany & Texas \\
\hline \multicolumn{3}{|l|}{ Upper Break-even Price } \\
\hline Contribution margin of hydrogen $C M_{h}\left(p^{*}\right)$ & $3.75 € \mathrm{c} / \mathrm{kWh}$ & $2.62 \$ \mathrm{c} / \mathrm{kWh}$ \\
\hline Break-even price for hydrogen, $p^{*}$ & $3.41 € / \mathrm{kg}$ & $2.59 \$ / \mathrm{kg}$ \\
\hline Capacity factor for hydrogen, $C F_{h}\left(p^{*}\right)$ & 0.99 & 0.94 \\
\hline Contribution margin of electricity, $C M_{e}\left(p^{*}\right)$ & $0.00 € \dot{c} / \mathrm{kWh}$ & $1.17 \$ \mathrm{c} / \mathrm{kWh}$ \\
\hline Capacity factor for electricity, $C F_{e}\left(p^{*}\right)$ & 0.00 & 0.02 \\
\hline \multicolumn{3}{|l|}{ Lower Break-even Price } \\
\hline Contribution margin of hydrogen $C M_{h}\left(p_{*}\right)$ & $0.03 € \dot{c} / \mathrm{kWh}$ & $0.00 \$ \mathrm{c} / \mathrm{kWh}$ \\
\hline Break-even price for hydrogen, $p_{*}$ & $0.02 € / \mathrm{kg}$ & $-0.01 \$ / \mathrm{kg}$ \\
\hline Capacity factor for hydrogen, $C F_{h}\left(p_{*}\right)$ & 0.02 & 0.00 \\
\hline Contribution margin of electricity, $C M_{e}\left(p_{*}\right)$ & $3.71 € \dot{c} / \mathrm{kWh}$ & $3.82 \$ \mathrm{c} / \mathrm{kWh}$ \\
\hline Capacity factor for electricity, $C F_{e}\left(p_{*}\right)$ & 0.97 & 1.00 \\
\hline \multicolumn{3}{|l|}{ Either Break-even Price } \\
\hline Levelized fixed cost, $L F C$ & 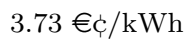 & $3.79 \$ \mathrm{c} / \mathrm{kWh}$ \\
\hline Levelized fixed operating cost, $f$ & $0.86 € \mathrm{c} / \mathrm{kWh}$ & $0.96 \$ c / k W h$ \\
\hline Levelized capacity cost, $c$ & $2.58 € \mathrm{c} / \mathrm{kWh}$ & $3.29 \$ \mathrm{c} / \mathrm{kWh}$ \\
\hline Tax factor, $\Delta$ & 1.11 & 0.86 \\
\hline
\end{tabular}

\section{Supplementary Table 8. Prospects, Germany.}

\begin{tabular}{cccccccccccc}
\hline Year & $\begin{array}{c}v_{h}^{o} \\
(€ / \mathrm{kW})\end{array}$ & $\begin{array}{c}\eta_{h}^{o} \\
(\mathrm{kWh} / \mathrm{kg})\end{array}$ & $\begin{array}{c}p_{h}^{o} \\
(€ / \mathrm{kg})\end{array}$ & $\begin{array}{c}p_{e}^{o} \\
(€ / \mathrm{kg})\end{array}$ & $\begin{array}{c}v \\
(€ / \mathrm{kW})\end{array}$ & $\begin{array}{c}\eta_{h} \\
(\mathrm{kWh} / \mathrm{kg})\end{array}$ & $\begin{array}{c}\eta_{e} \\
(\mathrm{kWh} / \mathrm{kg})\end{array}$ & $\begin{array}{c}p^{*} \\
(€ / \mathrm{kg})\end{array}$ & $\begin{array}{c}p_{*} \\
(€ / \mathrm{kg})\end{array}$ & $\begin{array}{c}\bar{p} \\
(€ / \mathrm{kg})\end{array}$ & $\begin{array}{c}p \\
(€ / \mathrm{kg})\end{array}$ \\
\hline 2019 & 1,606 & 0.02 & 3.19 & 0.54 & 2243.00 & 0.02 & 20.00 & 3.41 & 0.02 & 2.43 & -1.81 \\
2020 & 1,530 & 0.02 & 3.09 & 0.54 & 2042.00 & 0.02 & 20.15 & 3.25 & 0.09 & 2.45 & -1.82 \\
2021 & 1,457 & 0.02 & 2.99 & 0.54 & 1859.00 & 0.02 & 20.30 & 3.11 & 0.15 & 2.47 & -1.83 \\
2022 & 1,387 & 0.02 & 2.90 & 0.54 & 1693.00 & 0.02 & 20.45 & 2.98 & 0.22 & 2.49 & -1.85 \\
2023 & 1,321 & 0.02 & 2.82 & 0.54 & 1541.00 & 0.02 & 20.61 & 2.86 & 0.27 & 2.51 & -1.86 \\
2024 & 1,258 & 0.02 & 2.74 & 0.54 & 1403.00 & 0.02 & 20.76 & 2.75 & 0.33 & 2.53 & -1.87 \\
2025 & 1,198 & 0.02 & 2.66 & 0.54 & 1278.00 & 0.02 & 20.91 & 2.65 & 0.38 & 2.54 & -1.89 \\
2026 & 1,141 & 0.02 & 2.58 & 0.54 & 1163.00 & 0.02 & 21.06 & 2.55 & 0.42 & 2.56 & -1.90 \\
2027 & 1,086 & 0.02 & 2.51 & 0.54 & 1059.00 & 0.02 & 21.21 & 2.47 & 0.47 & 2.58 & -1.91 \\
2028 & 1,035 & 0.02 & 2.44 & 0.54 & 964.00 & 0.02 & 21.36 & 2.39 & 0.51 & 2.60 & -1.93 \\
2029 & 985 & 0.02 & 2.38 & 0.54 & 878.00 & 0.02 & 21.52 & 2.31 & 0.55 & 2.62 & -1.94 \\
2030 & 938 & 0.02 & 2.32 & 0.54 & 799.00 & 0.02 & 21.67 & 2.24 & 0.59 & 2.64 & -1.96 \\
\hline
\end{tabular}


Supplementary Table 9. Prospects, Texas.

\begin{tabular}{|c|c|c|c|c|c|c|c|c|c|c|c|}
\hline Year & $\begin{array}{c}v_{h}^{o} \\
(\$ / \mathrm{kW})\end{array}$ & $\begin{array}{c}\eta_{h}^{o} \\
(\mathrm{kWh} / \mathrm{kg})\end{array}$ & $\begin{array}{c}p_{h}^{o} \\
(\$ / \mathrm{kg}) \\
\end{array}$ & $\begin{array}{c}p_{e}^{o} \\
(\$ / \mathrm{kg}) \\
\end{array}$ & $\begin{array}{c}v \\
(\$ / \mathrm{kW}) \\
\end{array}$ & $\begin{array}{c}\eta_{h} \\
(\mathrm{kWh} / \mathrm{kg})\end{array}$ & $\begin{array}{c}\eta_{e} \\
(\mathrm{kWh} / \mathrm{kg})\end{array}$ & $\begin{array}{c}p^{*} \\
(\$ / \mathrm{kg}) \\
\end{array}$ & $\begin{array}{c}p_{*} \\
(\$ / \mathrm{kg}) \\
\end{array}$ & $\begin{array}{c}\bar{p} \\
(\$ / \mathrm{kg})\end{array}$ & $\left(\$ \frac{p}{/ \mathrm{kg}}\right)$ \\
\hline 2019 & 1,799 & 0.02 & 2.86 & 1.30 & 2512.00 & 0.02 & 20.00 & 2.59 & -0.01 & $>5.00$ & 0.59 \\
\hline 2020 & 1,713 & 0.02 & 2.76 & 1.30 & 2287.00 & 0.02 & 20.15 & 2.42 & 0.06 & $>5.00$ & 0.58 \\
\hline 2021 & 1,631 & 0.02 & 2.67 & 1.30 & 2082.00 & 0.02 & 20.30 & 2.26 & 0.12 & $>5.00$ & 0.58 \\
\hline 2022 & 1,553 & 0.02 & 2.58 & 1.30 & 1896.00 & 0.02 & 20.45 & 2.11 & 0.18 & $>5.00$ & 0.58 \\
\hline 2023 & 1,479 & 0.02 & 2.49 & 1.30 & 1726.00 & 0.02 & 20.61 & 1.97 & 0.24 & $>5.00$ & 0.58 \\
\hline 2024 & 1,409 & 0.02 & 2.41 & 1.30 & 1572.00 & 0.02 & 20.76 & 1.84 & 0.29 & $>5.00$ & 0.58 \\
\hline 2025 & 1,342 & 0.02 & 2.34 & 1.30 & 1431.00 & 0.02 & 20.91 & 1.72 & 0.35 & $>5.00$ & 0.58 \\
\hline 2026 & 1,278 & 0.02 & 2.27 & 1.30 & 1303.00 & 0.02 & 21.06 & 1.60 & 0.41 & $>5.00$ & 0.57 \\
\hline 2027 & 1,217 & 0.02 & 2.20 & 1.30 & 1186.00 & 0.02 & 21.21 & 1.48 & 0.50 & $>5.00$ & 0.57 \\
\hline 2028 & 1,159 & 0.02 & 2.13 & 1.30 & 1080.00 & 0.02 & 21.36 & 1.35 & 0.64 & $>5.00$ & 0.57 \\
\hline 2029 & 1,103 & 0.02 & 2.07 & 1.30 & 983.00 & 0.02 & 21.52 & 1.16 & 0.91 & $>5.00$ & 0.57 \\
\hline 2030 & 1,051 & 0.02 & 2.01 & 1.30 & 895.00 & 0.02 & 21.67 & - & - & $>5.00$ & 0.57 \\
\hline
\end{tabular}

\section{Supplementary Note 1. Heating Costs}

To account for the cost of heating, we again adopt the framework of hourly operating decisions that underlies all our calculations. Thus, in the following $t$ is an integer with $1 \leq t \leq 8,760$ hours. For an integrated reversible PtG system, suppose that after it has been idle for a particular period of time, it takes the system $\Delta \cdot 60$ minutes to heat up to regular operating temperature after a cold start. During this heat-up phase, suppose the system incurs the full variable cost at full capacity utilization and, at the same time, obtains no output yet. In this arguably conservative representation, we then obtain the following "penalty" factor $\theta(t)$ that the system incurs during a heat-up phase:

$$
\theta(t)= \begin{cases}1-\Delta & \text { if } C F_{h}(t-1 \mid p)=C F_{e}(t-1 \mid p)=0 \\ 1 & \text { otherwise. }\end{cases}
$$

The corresponding contribution margins then are:

$$
C M_{h}\left(C F_{h}, t \mid p\right)=\left[\eta_{h}\left(C F_{h}\right) \cdot p \cdot \theta(t)-q(t)-w_{h}\right] \cdot C F_{h},
$$

for hydrogen production, and

$$
C M_{e}\left(C F_{e}, t \mid p\right)=\left[q(t) \cdot \theta(t)-\frac{p}{\eta_{e}\left(C F_{e}\right)}-w_{e}\right] \cdot C F_{e},
$$

for electricity. For modular reversible PtG systems, the corresponding equations are derived in direct analogy to the approach shown above. For a gas turbine, the cost of heating can be interpreted as the cost of a cold start-up. Note that the above specifications of the contribution margins constitute upper bounds, considering that electrolyzer and fuel cell technologies based on SOC or PEM can produce some output during heat-up yet at a diminished conversion efficiency 416 . Similarly, gas turbines can produce some output during the ramp-up to full capacity utilization after a cold start 17 .

We then evaluate the modified model framework in the same economic context as in Section 4 of the main body. Since the heat-up to operating temperature of either a modular or an integrated PtG system based on PEM (SOC) technology requires less than 10 (20) minutes 4 418, let $\Delta=\frac{1}{6}$ for the modular electrolyzer and $\Delta=\frac{1}{3}$ for an integrated system. Since cold start-up times for combined-cycle gas turbines can be below 60 minutes ${ }^{17}$, let here $\Delta=1$. Furthermore, suppose conservatively that either reversible PtG equipment has to heat up (start up) whenever it has been idle for at least 1 hour. The resulting break-even values in the current economic context are summarized in Supplementary Table 10. For the modular electrolyzer and the integrated system, these break-even values are relatively close (if not identical) to those shown 
Supplementary Table 10. Current economics including heating cost.

\begin{tabular}{lcc}
\hline & Germany & Texas \\
\hline Modular reversible PtG System & & \\
Break-even price of Power-to-Gas: $p_{h}^{o}$ & $3.19 € / \mathrm{kg}$ & $2.86 \$ / \mathrm{kg}$ \\
Break-even price of Gas-to-Power: $p_{e}^{o}$ & $0.53 € / \mathrm{kg}$ & $0.79 \$ / \mathrm{kg}$ \\
Integrated reversible PtG System & & \\
Upper break-even price: $p^{*}$ & $3.41 € / \mathrm{kg}$ & $2.63 \$ / \mathrm{kg}$ \\
Lower break-even price: $p_{*}$ & $0.02 € / \mathrm{kg}$ & $-0.01 \$ / \mathrm{kg}$ \\
Upper critical price: $\bar{p}$ & $1.99 € / \mathrm{kg}$ & $>5.0 \$ / \mathrm{kg}$ \\
Lower critical price: $\underline{p}$ & $-1.81 € / \mathrm{kg}$ & $0.80 \$ / \mathrm{kg}$ \\
\hline
\end{tabular}

in Table 2 of the main body. The break-even price for the modular gas turbine in Texas is now about $40 \%$ lower.

\section{Supplementary Note 2. Sensitivity to Conversion Efficiencies}

We examine the sensitivity of our numerical findings for integrated reversible PtG systems based on SOC technology to changes in the conversion efficiencies in two regards. First, we examine the possibility that the conversion rates at full capacity utilization are higher or lower than the values we identified in the literature. For that, we run the corresponding calculations of Section 4 of the main body for both jurisdictions assuming for brevity that each conversion rate is adjusted by the same factor $\Delta \in[-20 \%,+20 \%]$. The resulting $\%$-change in the relevant prices for hydrogen is summarized in Supplementary Figure 1.

Figure 1 shows that the insights obtained from the main body of the paper remain are generally robust to the relatively wide range of changes in the conversion rates. The lower break-even price for hydrogen of an integrated system in either Germany or Texas is unaffected by a change in conversion efficiencies. The lower critical hydrogen price of an integrated system in Germany is upward sloping, because the underlying hydrogen price is negative. In absolute terms, the lower critical hydrogen price declines as the conversion efficiency increases.

In the second sensitivity analysis, we examine the trade-off between full and partial capacity utilization that could arise if the conversion rates of a unitized regenerative SOC fuel cell were to increase significantly at capacity utilization rates of less than $100 \%$. Given the lack of evidence regarding the shape of the functions $\eta_{h}(\cdot)$ and $\eta_{e}(\cdot)$, we first examine, in particular, the increase in both conversion rates that must be obtained if the integrated reversible PtG system operated at or below a particular capacity utilization of less than $100 \%$ such that the upper break-even price for hydrogen remains unchanged. We use the upper break-even price as the measure of indifference, because the integrated PtG system produces mostly produces hydrogen.

If hypothetically the integrated system were to achieve its maximum conversion rates at $70 \%$ capacity utilization, we find that the two conversion rates would each have to increase by $20.8 \%$ in Germany and $28.5 \%$ in Texas for the upper break-even price for hydrogen to remain unchanged. Thus, if for the system in Texas $\eta_{h}\left(C F_{h}=0.7\right)$ and $\eta_{e}\left(C F_{e}=0.7\right)$ is 1.285 times the corresponding values at full capacity utilization, the system would attain the same competitive position by operating at full capacity utilization despite the lower conversion rates. This analysis shows that the two conversion rates would have to decrease steeply for capacity utilization values approaching one for the integrated system to obtain a higher net present value by operating at partial load.

To further explore the magnitude of such a potential trade-off, let $\eta_{h}\left(C F_{h}=0.7\right)$ and $\eta_{e}\left(C F_{e}=0.7\right)$ hypothetically each amount to values that are as much as $35 \%$ above those 

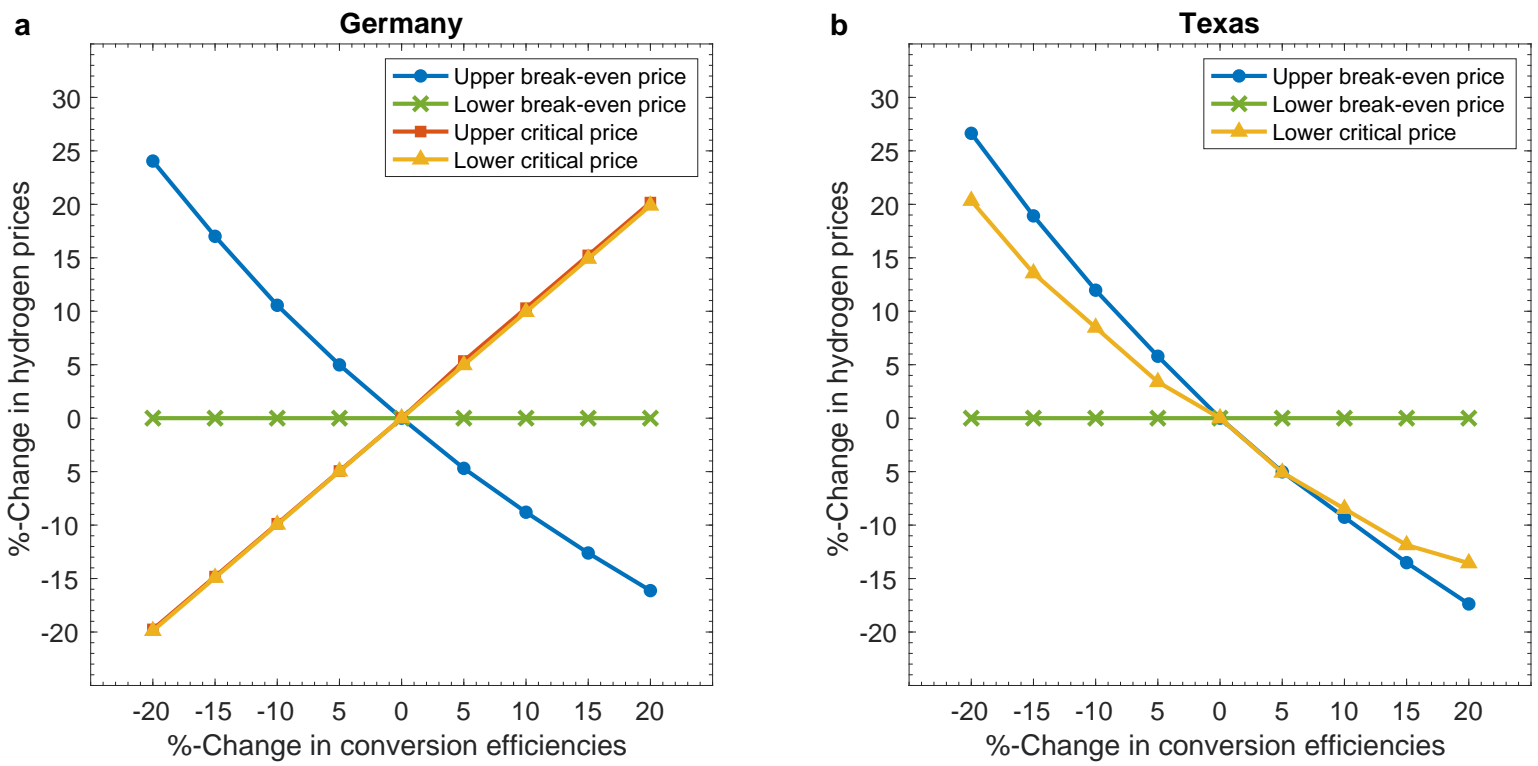

Supplementary Figure 1. Sensitivity to alternative conversion efficiencies. a,b, This figure shows the \%-change in break-even prices for hydrogen of integrated reversible Powerto-Gas systems in (a) Germany and (b) Texas as a function of the same \%-change in both conversion efficiencies of the system. The upper critical price for the integrated system in Texas is consistently above $5.0 \$ / \mathrm{kg}$ and therefore omitted.

at full capacity utilization. The resulting upper break-even price for the integrated system for the scenario calculated in Section 4 of the main body then amounts to $3.06 € / \mathrm{kg}$ in Germany and $2.46 \$ / \mathrm{kg}$ in Texas. These values are about $10 \%$ and $5 \%$ lower than the respective upper break-even prices obtained for the scenario calculated in Section 4. This analysis shows that even if conversion rates at a $70 \%$ utilization increased as steeply as 1.35 times the corresponding values at full capacity utilization, the overall effect on the competitive position of the integrated system is relatively minor. The reason is that the increase in conversion efficiencies is partially offset by the falling capacity utilization.

\section{Supplementary Note 3. Real-time Market Prices for Electricity}

We also run our calculations using hourly prices for electricity from 2019 for the real-time wholesale market in Texas. The resulting break-even prices for the current economic environment are shown in Supplementary Table 11. As it can be seen, differences of corresponding breakeven values between day-ahead and real-time market prices for electricity are small if observable at all. Break-even prices for modular gas turbines are now borderline to hydrogen prices for industrial-scale supply. 


\section{Supplementary Table 11. Current economics based}

on real-time prices for Texas.

\begin{tabular}{lc}
\hline & Texas \\
\hline Modular reversible PtG System & \\
Break-even price of Power-to-Gas: $p_{h}^{o}$ & $2.85 \$ / \mathrm{kg}$ \\
Break-even price of Gas-to-Power: $p_{e}^{o}$ & $1.53 \$ / \mathrm{kg}$ \\
Integrated reversible PtG System & \\
Upper break-even price: $p^{*}$ & $2.57 \$ / \mathrm{kg}$ \\
Lower break-even price: $p_{*}$ & $0.00 \$ / \mathrm{kg}$ \\
Upper critical price: $\bar{p}$ & $>5.0 \$ / \mathrm{kg}$ \\
Lower critical price: $\underline{p}$ & $-0.03 \$ / \mathrm{kg}$ \\
\hline
\end{tabular}

\section{Supplementary References}

[1] Glenk, G. \& Reichelstein, S. Economics of Converting Renewable Power to Hydrogen. Nature Energy 4, 216-222 (2019).

[2] IEA. The Future of Hydrogen. Tech. Rep. (2019).

[3] Michalski, J. et al. Hydrogen generation by electrolysis and storage in salt caverns: Potentials, economics and systems aspects with regard to the German energy transition. International Journal of Hydrogen Energy 42, 13427-13443 (2017).

[4] Buttler, A. \& Spliethoff, H. Current status of water electrolysis for energy storage, grid balancing and sector coupling via power-to-gas and power-to-liquids: A review. Renewable and Sustainable Energy Reviews 82, 2440-2454 (2018).

[5] Bundesfinanzhof. BFH-Urteil 14.04.2011 IV R 52/10 (Bundesfinanzhof, 2011).

[6] U.S. Congress. H.R.1: An Act to provide for reconciliation pursuant to titles II and V of the concurrent resolution on the budget for fiscal year 2018. (2017).

[7] Fraunhofer ISI. The impact of risks in renewable energy investments and the role of smart policies. Tech. Rep. (2016).

[8] Moné, C., Stehly, T., Maples, B. \& Settle, E. 2014 Cost of Wind Energy Review. Tech. Rep. February (2015).

[9] Weidner, E., Ortiz Cebolla, R. \& Davies, J. Global deployment of large capacity stationary fuel cells. Tech. Rep. (2019).

[10] SunFire GmbH. Technology details of our SOEC. Tech. Rep. (2018).

[11] Peterson, D. \& Miller, E. Hydrogen production cost from solid oxide electrolysis. Tech. Rep. (2016). URL http://hydrogen.energy .gov/pdfs/9014\{_\}hydrogen\{_\}storage\{_\}materials.pdf.

[12] U.S. Department of Energy. Report on the Status of the Solid Oxide Fuel Cell Program. Tech. Rep. August (2019).

[13] Elcogen. Solid Oxide Fuel Cells: Opportunities for a clean energy future. Tech. Rep. (2019).

[14] CenterPoint Energy Houston Electric. Tariff for Retail Delivery Service (2020). URL http://bit. Iy/3820F J0

[15] Griddy. Pricing (2020). URL http://bit.ly/382npZk.

[16] Mogensen, M. B. et al. Reversible solid-oxide cells for clean and sustainable energy. Clean Energy 3, 175-201 (2019).

[17] U.S. EIA. About 25\% of U.S. power plants can start up within an hour. 07.06.2021 (2020). URL https://www.eia.gov/todayinenergy/detail.php?id=45956 
[18] Beney, A. M. Investigation into the Heat Up Time for Solid Oxide Fuel Cells in Automotive Applications. Tech. Rep. (2018). 